\title{
Comparative morphology of female flowers and systematics in Geonomeae (Arecaceae)
}

\author{
Stauffer, F W ; Endress, P K
}

\begin{abstract}
Female floral structure is compared in Geonomeae (Arecaceae). A perianth is formed by two alternate whorls of three basally congenitally united and imbricate sepals and three basally congenitally united and apically valvate petals. A sterile androecium is formed by a variable number of staminodes, which are united into a tube. The gynoecium shows three more or less equally developed carpels or is pseudomonomerous (Geonoma). The single anatropous ovule per carpel is median, either basal or at mid-height of the ovary. A septal nectary is present at the base and mid-height of the ovaries and exits at different levels of the ovary. Carpels in pseudomonomerous gynoecia seem to be "basistylous", but the styles are more lateral or apical in gynoecia with all three carpels equally developed. Stigmas expose unicellular or multicellular (Welfia) papillae at anthesis. Pollen tube transmitting tracts and a compitum are present in the ventral slits of the postgenitally united styles. Floral structure in Geonomeae is compared with other Arecaceae, especially Arecoideae, in a morphological and systematic context
\end{abstract}

DOI: https://doi.org/10.1007/s00606-003-0030-1

Posted at the Zurich Open Repository and Archive, University of Zurich

ZORA URL: https://doi.org/10.5167/uzh-156441

Journal Article

Published Version

Originally published at:

Stauffer, F W; Endress, P K (2003). Comparative morphology of female flowers and systematics in Geonomeae (Arecaceae). Plant Systematics and Evolution, 242(1-4):171-203.

DOI: https://doi.org/10.1007/s00606-003-0030-1 


\title{
Comparative morphology of female flowers and systematics in Geonomeae (Arecaceae)
}

\author{
F. W. Stauffer and P. K. Endress \\ Institute of Systematic Botany, University of Zurich, Zurich Switzerland
}

Received April 29, 2003; accepted May 2, 2003

Published online: November 6, 2003

(C) Springer-Verlag 2003

\begin{abstract}
Female floral structure is compared in Geonomeae (Arecaceae). A perianth is formed by two alternate whorls of three basally congenitally united and imbricate sepals and three basally congenitally united and apically valvate petals. A sterile androecium is formed by a variable number of staminodes, which are united into a tube. The gynoecium shows three more or less equally developed carpels or is pseudomonomerous (Geonoma). The single anatropous ovule per carpel is median, either basal or at mid-height of the ovary. A septal nectary is present at the base and mid-height of the ovaries and exits at different levels of the ovary. Carpels in pseudomonomerous gynoecia seem to be "basistylous", but the styles are more lateral or apical in gynoecia with all three carpels equally developed. Stigmas expose unicellular or multicellular (Welfia) papillae at anthesis. Pollen tube transmitting tracts and a compitum are present in the ventral slits of the postgenitally united styles. Floral structure in Geonomeae is compared with other Arecaceae, especially Arecoideae, in a morphological and systematic context.
\end{abstract}

Key words: Arecaceae, Geonomeae, female floral structure, staminodia, morphology, systematics.

\section{Introduction}

Geonomeae (Arecoideae, Arecaceae) contain sixgenera: Pholidostachys, Welfia, Calyptronoma, Calyptrogyne, Asterogyne and Geonoma (Uhl and Dransfield 1987, Dransfield and Uhl 1998) and up to 70 species (Henderson et al. 1995). They are almost exclusively neotropical, with a distribution from south eastern Mexico through Central America, the Antilles, and the tropics of South America, south to Bolivia and Paraguay (Wessels Boer 1968). Geonomeae are mostly small to medium-sized understory palms, dominant and rich in species from the lowland rain forest up to the high elevation cloud forest. Only the monotypic Welfia grows in the sub-canopy. Flowers deeply sunken in pits, floral parts of all whorls united, at least at the base, and elongate and slender styles are in general considered to be the main shared characters within Geonomeae (Uhl and Dransfield 1987).

Geonomeae were found to be monophyletic by Asmussen (1999a, 1999b) based on plastid rps16 DNA sequences, by Hahn (2002) based on $a t p \mathrm{~B}, \quad r b c \mathrm{~L}$, and $18 \mathrm{~S}$ nrDNA 
sequences, and recently by Roncal et al. (2002) based on the nuclear gene phosphoribulokinase (PRK) and intron 23 of RNA polymerase II subunit 2 (RPB2). The relationships of Geonomeae with other tribes within Arecoideae are still uncertain (Uhl et al. 1995), and the study by Asmussen and Chase (2001), based on sequences from $r b c \mathrm{~L}$, rps 16 intron and $\operatorname{trn} \mathrm{L}-\operatorname{trn} \mathrm{F}$, indicated that its sister relation with Euterpeinae warrants further investigation, and may eventually suggest the reduction of Geonomeae to a subtribe within Areceae.

With the circumscription of Geonomeae, Drude $(1881,1889)$ described several aspects of the reproductive structures and emphasized the morphological diversity displayed by the stamens and staminodes. Floral morphology in the tribe has also been preliminarily described by Burret (1930), Wessels Boer (1968) and Uhl and Dransfield (1987). Detailed studies on the reproductive structures were carried out in less than eight species of Geonomeae, restricted to Asterogyne (Uhl 1966, Schmid 1970a, Stauffer et al. in press) and Geonoma (Gassner 1941, Uhl and Moore 1971). Floral development was only studied in male flowers of Welfia regia (as W. georgii) (Uhl and Moore 1980, Uhl and Dransfield 1984, Uhl 1988) and female flowers of Geonoma interrupta (Stauffer et al. 2002). Floral structure of the remaining genera of Geonomeae (Pholidostachys, Calyptronoma and Calyptrogyne) has never been studied in detail.

As the female flowers of Geonomeae are apparently less diverse than the male ones (Wessels Boer 1968) their characteristics have largely been neglected in infratribal classifications and generic treatments (e.g. Drude 1889, Burret 1930, Wessels Boer 1968, Moore 1973, Uhl and Dransfield 1987, Zona 1995). The aim of this study is to answer the following questions: 1) What are the structural features in the female flowers in Geonomeae? 2) Do these features support recent molecular phylogenetic analyses? and 3) How does the floral structure of Geonomeae compare to other Arecoideae?

\section{Material and methods}

Female flowers of 15 species in six genera of Geonomeae (Table 1) were obtained from the

Table 1. List of material studied (species, collection, origin, stage of development)

Pholidostachys pulchra H. Wendl. ex Burret, J. Knudsen \& C. Asmussen (655-AAU), Costa Rica, young buds; H. E. Moore \& M. V. Parthasarathy (9410-BH), Costa Rica, anthetic flowers.

P. synanthera (Mart.) H. E. Moore, H. Balslev et al. (60678-AAU), Ecuador, anthetic flowers; R. Bernal (2588-AAU), Colombia, young buds.

Welfia regia H. Wendl. ex André, H. E. Moore \& M. V. Parthasarathy (9412-BH), Costa Rica, old buds. Calyptronoma rivalis (O.F. Cook) L.H. Bailey, S. Zona (864-FTG), Puerto Rico, anthetic and pre-anthetic flowers; S. Zona (81-292-FTG), Puerto Rico, young buds.

Calyptrogyne costatifrons (L.H. Bailey) Nevers, J. Knudsen \& C. Asmussen (610-AAU), Panama, anthetic flowers.

C. ghiesbreghtiana. (Linden \& H. Wendl.) H. Wendl., J. Knudsen \& C. Asmussen (628-AAU), Panama, old buds; Murray (01-BH), Central America, old buds.

Asterogyne martiana (H. Wendl.) H. Wendl. ex Hemsl., J. Knudsen (00:65-private collection), Costa Rica, young buds; J. Knudsen \& C. Asmussen (604-AAU), Panama, anthetic flowers.

A. ramosa (H.E. Moore) Wess. Boer, F. W. Stauffer (824-Z), Venezuela, old buds.

A. spicata (H.E. Moore) Wess. Boer, F. W. Stauffer (822-Z), Venezuela, old buds.

A. yaracuyense Henderson and Steyerm., F. W. Stauffer (823-Z), Venezuela, old buds.

Geonoma cuneata H. Wendl. ex Spruce, C. Listabarth (40-Z), Peru, old buds.

G. interrupta (Ruiz \& Pav.) Mart., F. W. Stauffer (15-Z), Venezuela, young and old buds, anthetic flowers.

G. macrostachys Mart., C. Listabarth (s.n.-W), Peru, young buds.

G. maxima (Poit.) Kunth, J. Knudsen (98:118-AAU), Ecuador, young buds.

G. simplicifrons Willd., F. W. Stauffer (13, s.n.-Z), Venezuela, old buds and anthetic flowers. 
pickled collections deposited at $\mathrm{AAU}, \mathrm{BH}, \mathrm{K}$ and collections made by Christian Listabarth (Austrian Academy of Science), Jette Knudsen (University of Göteborg) and Scott Zona (Fairchild Tropical Garden). Flowers were also removed from herbarium specimens deposited at AAU and US for anatomical study. Reproductive structures of Geonoma interrupta, G. simplicifrons and three species of Asterogyne were collected by the first author in Venezuela between 1999 and 2002. In order to evaluate structural diversity within Geonoma, which contains up to 55 species (Henderson et al. 1995), a preliminary screen based on 26 taxa (Appendix 1) was performed.

For anatomical investigations, flowers in late bud or at anthesis, fixed in FAA or ethanol $(70 \%)$, were evacuated, dehydrated, and embedded in Kulzer's Technovit 7100 (2-hydroxyethyl methacrylate [HEMA]). Perianth and sometimes the sterile androecium were removed to facilitate infiltration. Further details on this technique are explained in Igersheim and Cichocki (1996). The material was transversally and longitudinally sectioned at six-seven $\mu \mathrm{m}$ using a rotary microtome (Microm HM-355, Microm Laborgeräte $\mathrm{GmbH}$, Walldorf, Germany), and then stained with ruthenium red and toluidine blue, and enclosed in Histomount ${ }^{(\mathrm{TM})}$. For scanning electron microscopy, the dissected specimens were dehydrated, critical-point dried, and sputter-coated with gold. All the permanent slides of the microtome sections are deposited at the Institute of Systematic Botany of the University of Zurich (Z). Arrangement of the genera follows Uhl and Dransfield (1987).

\section{Results}

Shared characters of the female flowers of Geonomeae. As in all Arecoideae (Uhl and Dransfield 1987), a female flower and two male flowers form a floral triad arranged in a cincinnus. Such floral triads in Geonomeae are sunken in pits of the inflorescence rachillae. Triads are protandrous. Anthesis of the staminate flowers occurs sequentially, or less commonly both flower at the same time (e.g. Pholidostachys dactyloides, Henderson 1986), but before the pistillate flower of the same triad is receptive. Subsequent development of the pistillate flower pushes the post-anthetic staminate flowers out of the pit. Perianth, sterile androecium and gynoecium show some features that are shared by all species studied.

The perianth is formed by two alternate whorls; the outer whorl has three basally congenitally united, apically imbricate sepals, and the inner whorl three basally congenitally united, apically valvate petals. Tanniferous tissue and cells with oxalate raphides are present in the sepals and petals, and are especially concentrated in the petal flanks. The perianth seems to be quite uniform in all taxa studied.

Staminodes are at least basally congenitally united into a tube and also have a common base with petals and carpels (Fig. 1). Tanniferous tissue and cells with oxalate raphides are present in the mesophyll of the staminodes.

The three carpels alternate with the petals. The stigmatic branches are erect and more or less connivent in bud, but spreading at anthesis. Secretory papillae cover the entire ventral surface of the stigmatic branches and are exposed during anthesis. The ventral slits extend from the top of the ovary, at the base of the plicate zone, up to the base of the styles; they are papillate, secretory and open. The carpels are congenitally united at the base, free at mid-height of the ovary, or slightly above (Calyptrogyne), but postgenitally united up to mid-height of the styles. Two carpels are adaxial and one carpel is abaxial. The terms adaxial and abaxial are here applied in a purely topographical and not in a comparative morphological sense, and they are related with the proximity to the main axis of the inflorescence rachilla. The gynoecium is synascidiate up to mid-height of the ovaries. Each ovary, if well developed, bears a crassinucellate, anatropous ovule, which has a median position (Fig. 1). In flowers at anthesis or shortly before, the presence of two integuments could not be ascertained (but see younger ovules in Geonoma maxima). The micropyle faces the ventral side of the locule (Fig. 1). A septal nectary is formed by incomplete union of the carpel flanks. The nectary is a triradiate cavity between the three carpels at mid-height of the ovaries and extends upwards and gradually 


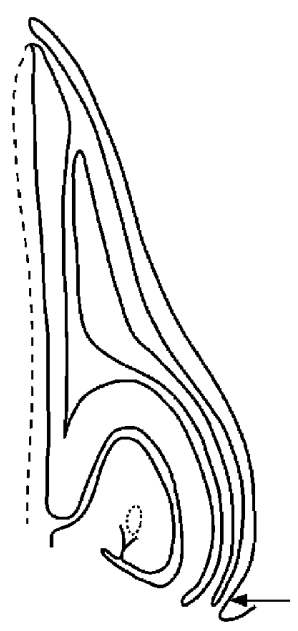

Geonoma

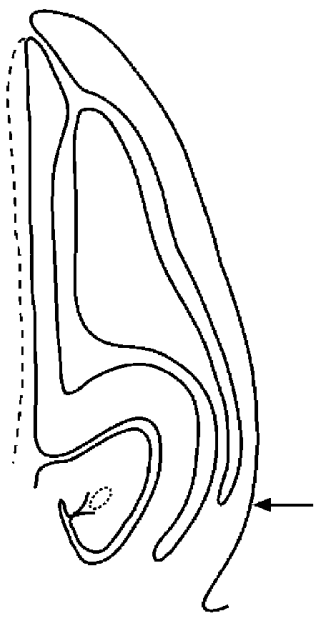

Pholidostachys

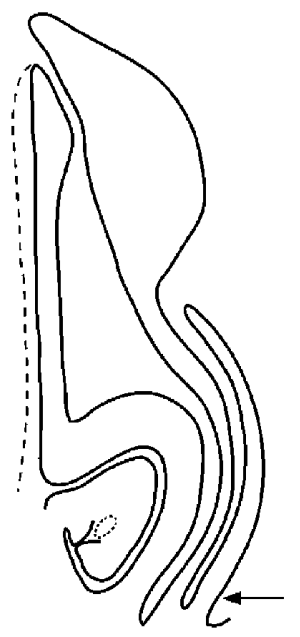

Calyptrogyne costatifrons

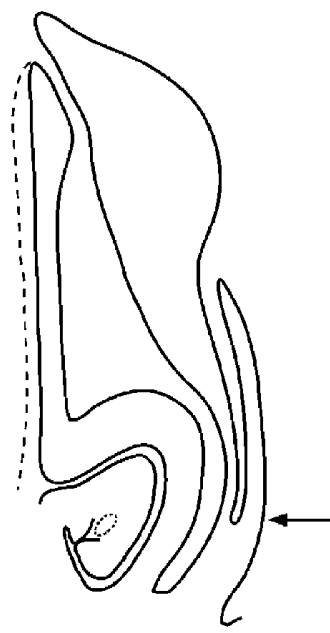

Calyptronoma

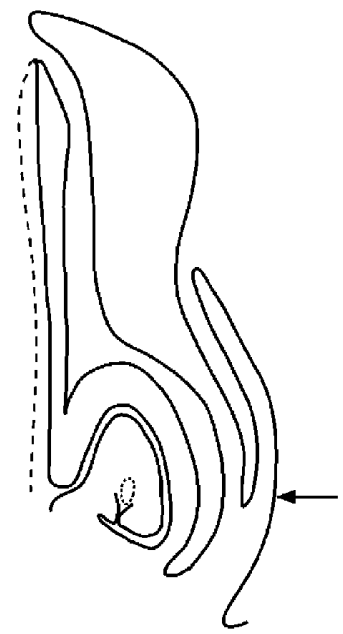

Calyptrogyne ghiesbreghtiana

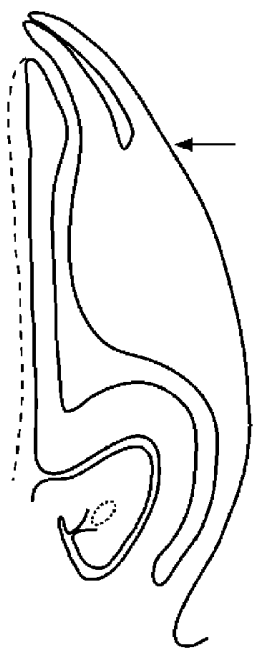

Asterogyne

Fig. 1. Schematic LS of female flowers in Geonomeae. Arrows point to the different levels of separation of the corolla from the sterile androecium. Floral buds (Geonoma, Pholidostachys, Asterogyne and Welfia), flowers shortly before anthesis (Calyptrogyne costatifrons, C. ghiesbreghtiana and Calyptronoma)

outwards to the apical region of the ovaries. It is formed by an epithelium of columnar, uninucleate cells. The openings of the nectary are non-secretory ducts with isodiametric epidermal cells. A pollen tube transmitting tract (PTTT) encompasses the epidermis of the ventral slits of the stigmas and styles. The individual tracts coming from the stigmatic branches join in a compitum at the level of postgenital union of the styles down to the level of the placenta. The PTTT reaches the micropyle by surrounding both flanks of the funiculus.

The dorsal bundle of each carpel extends up to the top of the stigmatic branches. In the synascidiate zone a complex ventral bundle is present in each carpel. A branch derived from this ventral bundle, in the upper synascidiate region, serves the ovule. Tanniferous tissue is present throughout the gynoecium, but is 


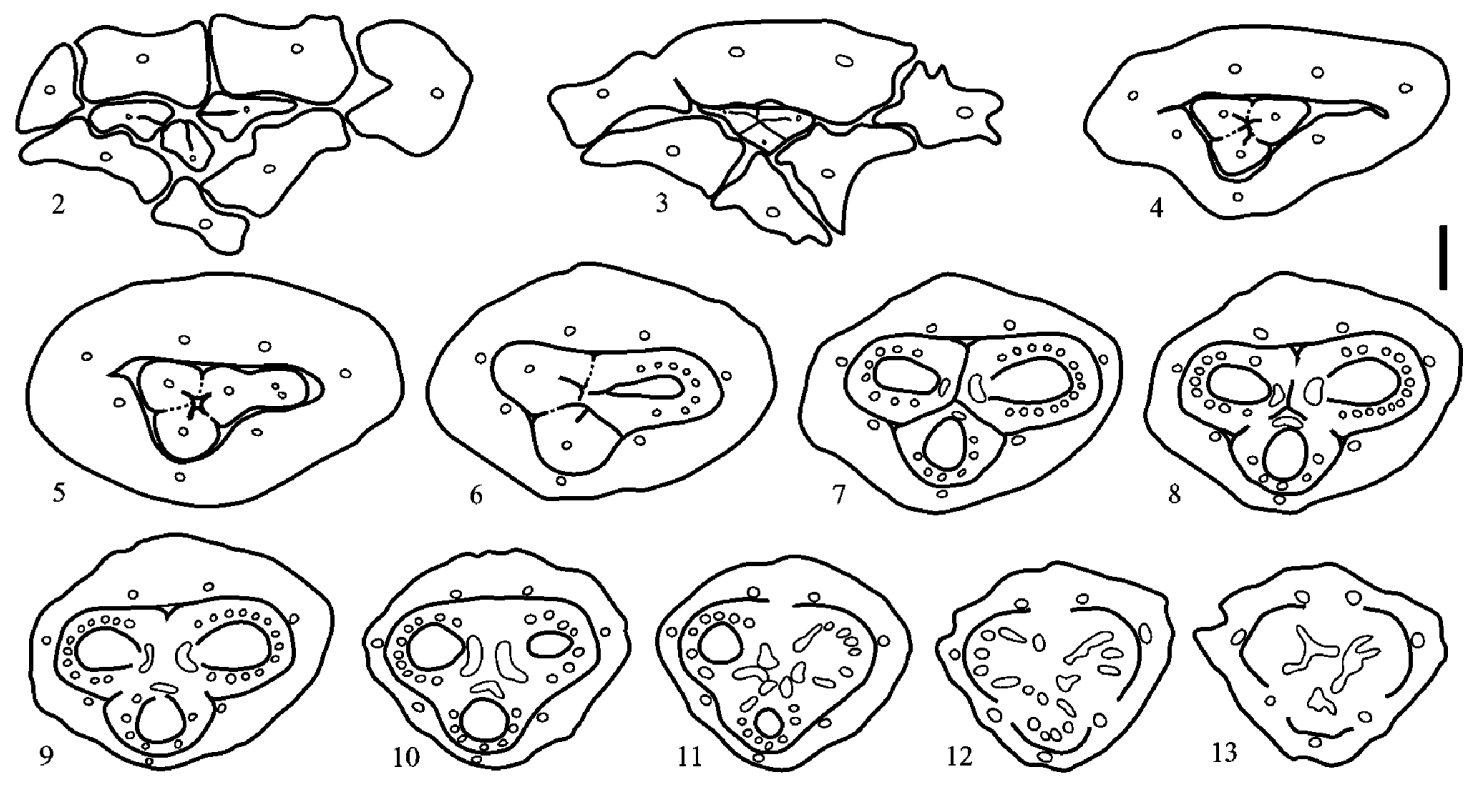

Figs. 2-13. Pholidostachys pulchra. Floral bud, TS series. Fig. 2. Level of free carpels (stigmas) and free staminodes. Figs. 3-5. Apocarpous styles; carpel flanks postgenitally united (dotted lines); staminodes congenitally united. Figs. 6-7. Apocarpous zone of ovaries above level of placentae; carpel flanks partially postgenitally united (dotted lines); zone with septal nectary. Figs. 8-11. Synascidiate zone at level of placentae and below; lower zone of septal nectary in 8 . Figs. 12-13. Floral base, androecium and gynoecium are partially congenitally fused. Scale bar $=200 \mu \mathrm{m}$

especially concentrated towards the apex of the stigmatic branches.

\section{Pholidostachys}

The staminodial tube separates from the corolla above the base of the flower (Fig. 1). The upper part of the androecium has six (Pholidostachys synanthera) (Fig. 21) or seven (P. pulchra) (Figs. 2, 14) free parts (staminodial lobes, according to the terminology of Uhl and Moore 1971, Uhl and Dransfield 1987), which are connivent in bud (Fig. 22), and spreading at anthesis (Figs. 14, 21). The staminodes become free first from the inner surface of the tube (Figs. 3, 4) and then also from the outer surface. Each staminode has a vascular bundle near the inner surface (Fig. 6), which forms a vascular trace at the base of the flower. Tanniferous tissue is abundant in the free part of the staminodes and upper tube. Cells with oxalate raphides are present at the base
(P. pulchra) and upper part of the staminodial tube, and at the base of the free parts of the staminodes.

At the base the carpels are congenitally united (Figs. 8, 9) and become free from the staminodial tube first in their median areas (Fig. 12). The two adaxial ovaries are more or less the same size (Fig. 19), or one of them is larger than the other ( $P$. pulchra). The abaxial ovary is always smaller (Figs. 7, 18, 23) All carpels have a well-developed ovule. The stigmatic branches may be equal ( $P$. synanthera) (Fig. 25) or unequal ( $P$. pulchra) (Fig. 15) in length. If unequal, the branch of the abaxial carpel is always shorter. At anthesis the stigmatic branches are at the same level as the free parts of the staminodes. The stigmatic branches resemble the free part of the staminodes in size and shape (Fig. 21). Unicellular papillae (Fig. 17) cover the ventral surface of the stigmatic branches (Fig. 16). The styles appear to be lateral in all carpels, or 


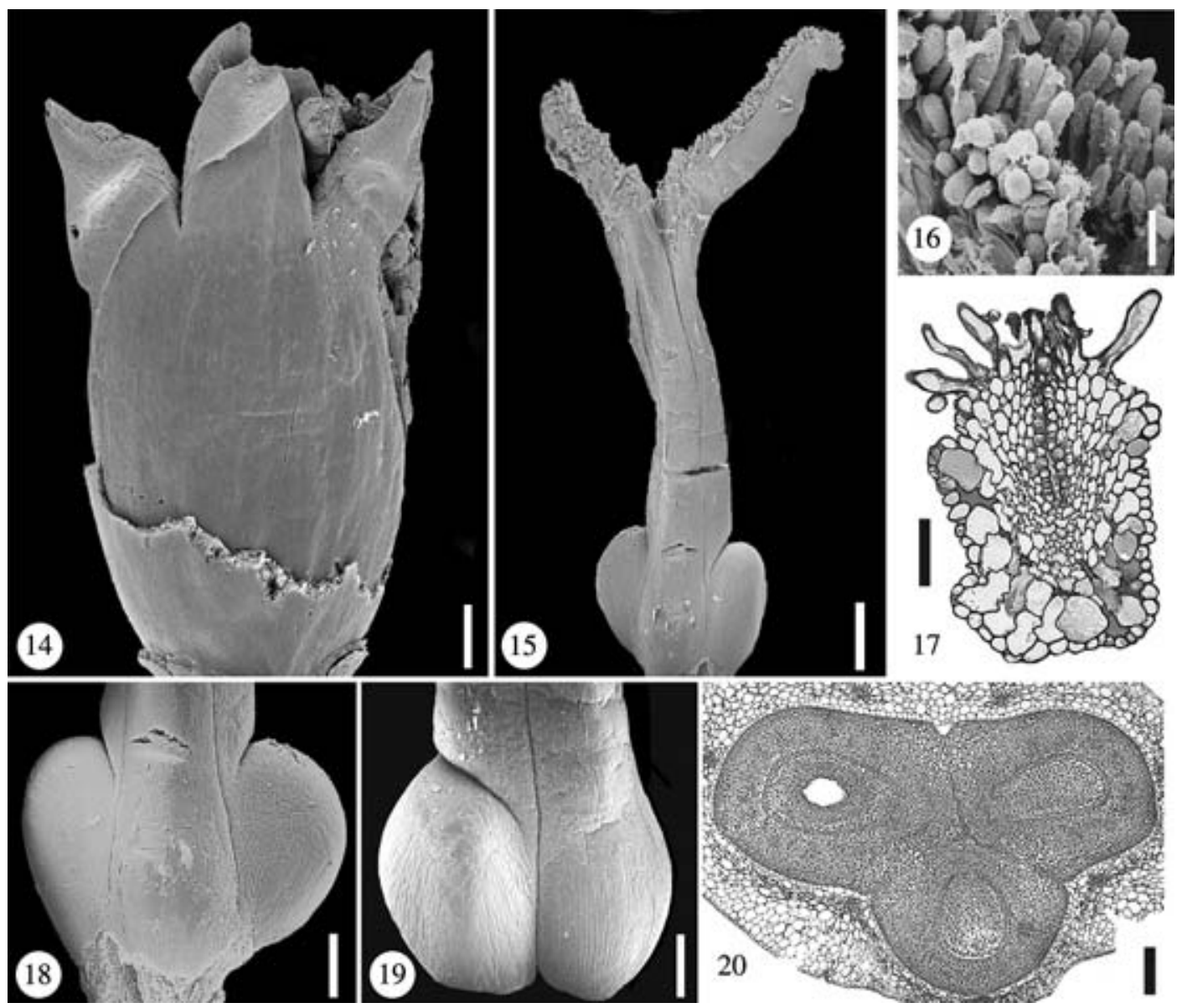

Figs. 14-20. Pholidostachys pulchra. Fig. 14. Flower at anthesis (perianth removed). Scale bar $=500 \mu \mathrm{m}$. Fig. 15. Gynoecium at anthesis. Scale bar $=500 \mu \mathrm{m}$. Fig. 16. Part of stigma. Scale bar $=100 \mu \mathrm{m}$. Fig. 17. TS of stigma showing unicellular papillae and tanniferous mesophyll. Scale bar $=50 \mu \mathrm{m}$. Fig. 18. Abaxial view of lower gynoecium, note the reduced size of the abaxial ovary. Scale bar $=400 \mu \mathrm{m}$. Fig. 19. Adaxial view of lower gynoecium, note that both adaxial ovaries have the same size and shape. Scale bar $=400 \mu \mathrm{m}$. Fig. 20. TS of gynoecium at the level of the ovaries. Scale bar $=200 \mu \mathrm{m}$

more or less apical in the abaxial carpel $(P$. pulchra). At the base of the styles the dorsal surface is smooth (P. pulchra) (Fig. 15) or it has conspicuous protrusions ( $P$. synanthera) (Fig. 24), which contain tissue with large and highly vacuolated cells (Fig. 26). The carpels begin to separate from each other either from the periphery or the center of the syncarpous zone (Fig. 8). At the base of the plicate zone the contiguous surfaces of adjacent carpels are papillate $(P$. pulchra). A central protrusion is present between the three carpels ( $P$. synan-

Figs. 21-28. Pholidostachys synanthera. Fig. 21. Flower at anthesis. Scale bar $=500 \mu \mathrm{m}$. Fig. 22. Flower in late bud (perianth removed); the free staminodes are connivent. Scale bar $=500 \mu \mathrm{m}$. Fig. 23. Gynoecium in late bud. Scale bar $=500 \mu \mathrm{m}$. Fig. 24. Gynoecium at anthesis; the styles show irregular protrusions towards the base. Scale bar $=500 \mu \mathrm{m}$. Fig. 25. Stigmas at anthesis showing receptive papillae. Scale bar $=500 \mu \mathrm{m}$. Fig. 26. TS of postgenitally united styles (towards the base); the irregular protrusions are formed by tanniferous parenchyma. Scale bar $=200 \mu \mathrm{m}$. Fig. 27. TS of ovaries (transition from synascidiate to apocarpous). Scale bar $=200 \mu \mathrm{m}$. Fig. 28. TS of ovaries showing central protrusion between the three carpels. Scale bar $=100 \mu \mathrm{m}$ 
F. W. Stauffer and P. K. Endress: Comparative morphology and systematics in Geonomeae
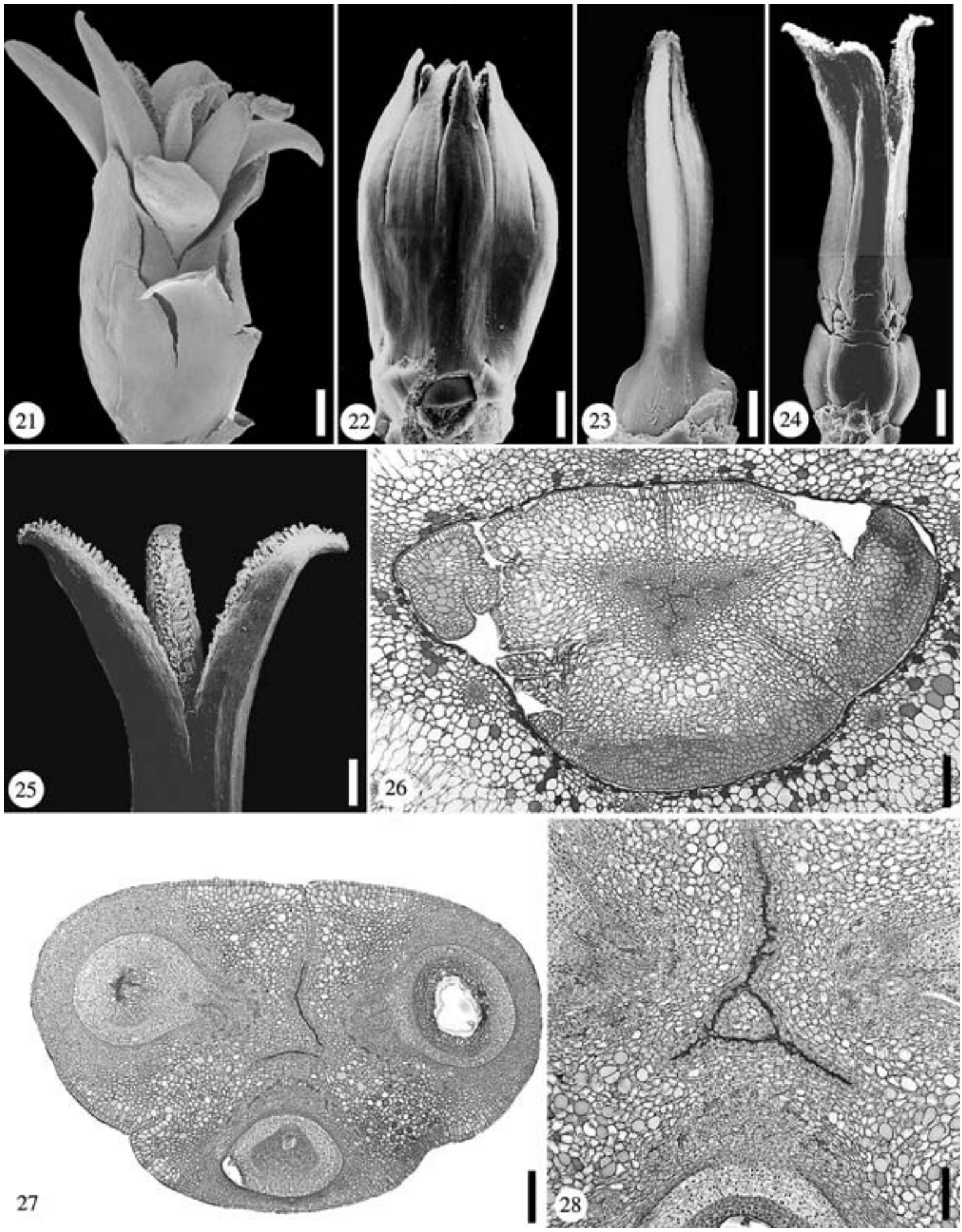

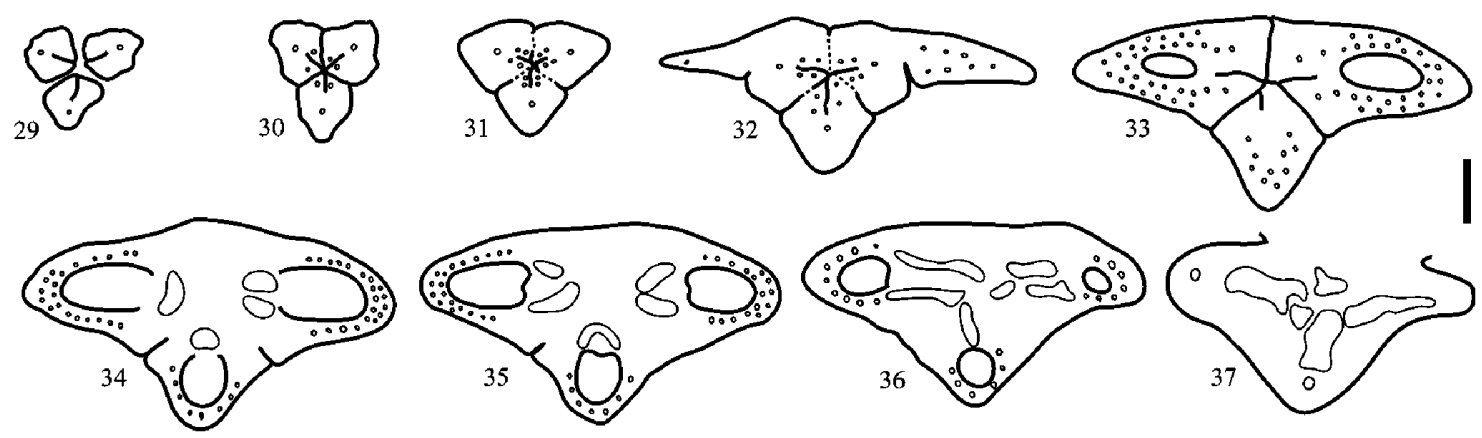

Figs. 29-37. Welfia regia. Floral bud, TS series. Fig. 29. Level of free carpels (stigmas). Figs. 30-32. Apocarpous styles; carpel flanks postgenitally united (dotted lines). Fig. 33. Apocarpous zone of ovaries above level of placentae; zone with septal nectary. Figs. 34-36. Synascidiate zone at level of placentae and below. Fig. 37. Floral base. Scale bar $=200 \mu \mathrm{m}$

thera) (Fig. 28), or absent (P. pulchra) (Fig. 7); it extends slightly above mid-height of the ovaries, and is secretory. The ovule is attached at mid-height of the ovary (Fig. 1). The septal nectary forms simple slits between the carpels (Fig. 7) at the base of the apocarpous part of the gynoecium and becomes a triradiate cavity at mid-height of the ovaries (Fig. 7). The openings of the nectary are towards the top of the ovaries.

Four to six lateral procambial strands on each side of the carpels extend from the top to mid-height of the ovary and merge into three to four lateral bundles towards the base of the ovary; they are small and undifferentiated at anthesis (Figs. 2-13). Some of the lateral bundles connect with the dorsal bundle at about the top of the ovary ( $P$. pulchra), or with the ventral bundles either near the base $(P$. synanthera) or near the top ( $P$. pulchra) of the ovary. Between ten (P. pulchra) and 13 (P. synanthera) large vascular traces from the gynoecium, more or less equal in shape, rearrange into a ring-shaped stele at the base of the flower. Tanniferous tissue is common towards the apex of the stigmas, particularly concentrated in the dorsal hypodermis, and also in the mesophyll of the styles, normally towards the dorsal surface, and throughout the mesophyll of the ovaries. Cells with oxalate raphides are concentrated in the mesophyll of the bulged upper part of the ovaries.

\section{Welfia}

The staminodial tube separates from the corolla in the upper half of the corolla, near the base of the free parts of the staminodes (Fig. 1). The 22 staminodes (15-16 according to Uhl and Dransfield 1987) are more or less connivent in bud (Fig. 38) and are spreading at anthesis. Tanniferous tissue is present throughout the mesophyll of the staminodes, including the tube and the free parts, particularly surrounding the vascular bundles. A few cells with oxalate raphides are present in the mesophyll of the staminodes (Fig. 45).

One of the two adaxial ovaries is the largest (Fig. 44) one and the abaxial ovary is the smallest (Fig. 43). All carpels have a welldeveloped ovule (Fig. 35). The ovaries are partially fused with the staminodial tube in the median areas of the carpels. The stigmatic branches are more or less equal in length (Figs. 39, 40). They have unicellular or multicellular papillae on their ventral surface (Figs. 41, 42, 46). The styles appear to be lateral in the two adaxial carpels and apical in the abaxial carpel. The carpels begin to separate from each other either from the periphery or the center of the syncarpous zone (Fig. 34). No central protrusion is present between the carpels. The ovule is attached at mid-height of the ovary (Fig. 1). The nectary forms a simple slit between the abaxial carpel and one of the 

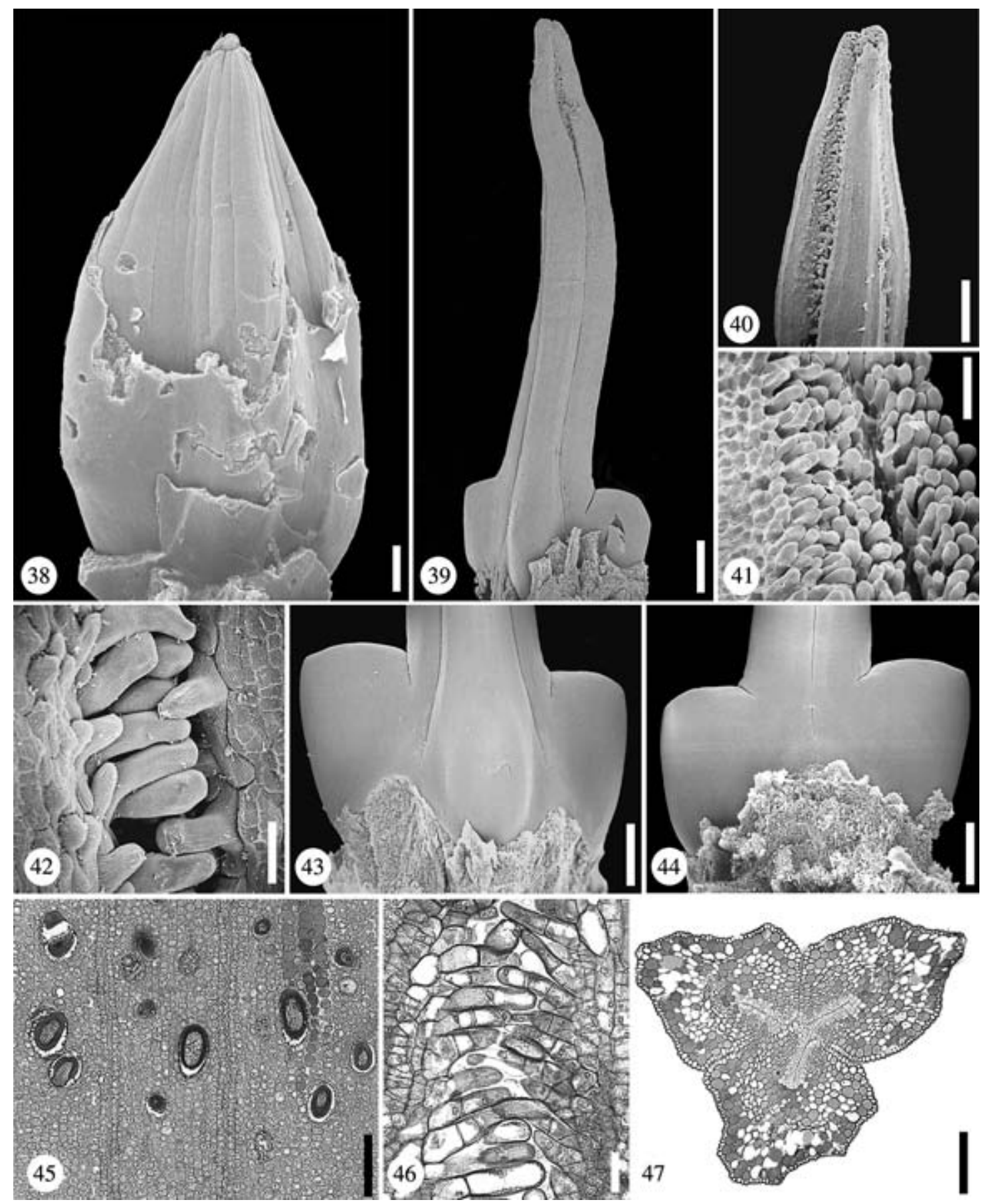

Figs. 38-47. Welfia regia. Fig. 38. Flower in late bud (calyx and upper part of corolla removed); the free staminodes are tightly connivent. Scale bar $=500 \mu \mathrm{m}$. Fig. 39. Gynoecium in late bud. Scale bar $=500 \mu \mathrm{m}$. Fig. 40. Stigmas in late bud. Scale bar $=400 \mu \mathrm{m}$. Fig. 41. Detail of stigmas in late bud showing large papillae. Scale bar $=100 \mu \mathrm{m}$. Fig. 42. Stigmatic papillae. Scale bar $=100 \mu \mathrm{m}$. Fig. 43. Abaxial view of lower gynoecium, note the reduced size of the abaxial ovary. Scale bar $=1 \mathrm{~mm}$. Fig. 44. Adaxial view of lower gynoecium. Scale bar $=1 \mathrm{~mm}$. Fig. 45. LS of the sterile androecium (detail) showing raphide idioblasts. Scale bar $=150 \mu \mathrm{m}$. Fig. 46. LS of stigmas in late bud showing multicellular papillae. Scale bar $=50 \mu \mathrm{m}$. Fig. 47. TS of postgenitally united styles with tanniferous parenchyma. Scale bar $=200 \mu \mathrm{m}$ 

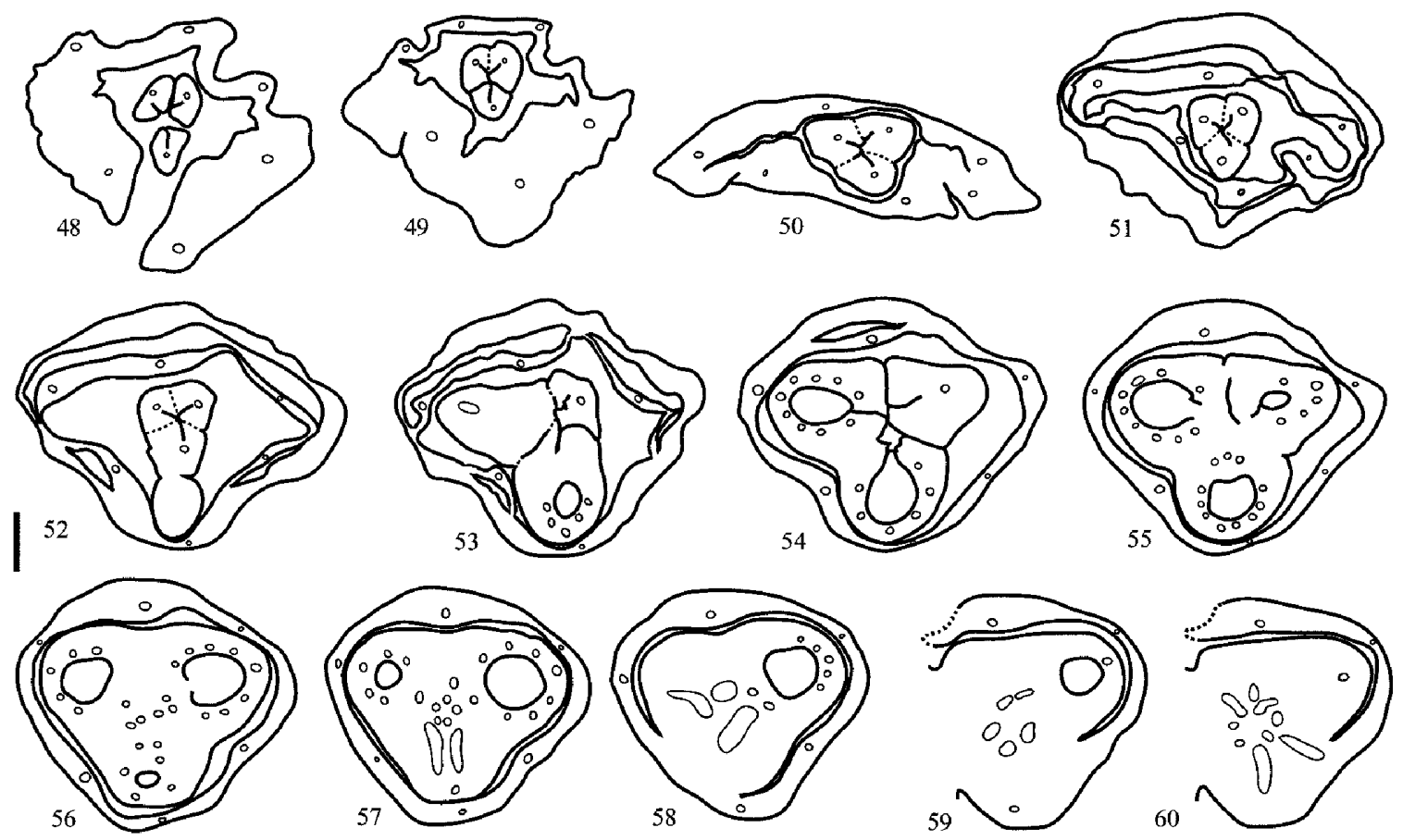

Figs. 48-60. Calyptronoma rivalis. Floral bud, TS series. Fig. 48. Level of free carpels (stigmas) and congenitally united bulged out staminodes. Figs. 49-52. Apocarpous styles; carpel flanks postgenitally united (dotted lines); staminodes congenitally united and separating from the corolla. Figs. 53-54. Apocarpous zone of ovaries above level of placentae; zone with septal nectary and central protrusion between carpels. Figs. 55-58. Synascidiate zone at level of placentae and below. Figs. 59-60. Lower synascidiate zone and floral base; calyx, corolla, androecium and gynoecium are congenitally fused; interrupted lines: part not complete. Scale bar $=200 \mu \mathrm{m}$

adaxial carpels at mid-height of the ovaries, and becomes a triradiate cavity towards the top (Fig. 33). The three openings of the nectary are towards the top of the ovaries.

Between two and three lateral bundles on each side of the ventral slit extend from the base of the stigmatic branches to the top of the ovary (Figs. 30, 32). In addition, at anthesis a double series of 10-12 procambial strands on each side of the carpel extend from the upper part of the ovary to mid-height of the ovary and merge into one series of three to four small and undifferentiated lateral bundles towards the base of the ovary (Figs. 32, 35). Some of the lateral bundles connect with the ventral bundle towards the base of the ovary. Two large branches derived from the ventral bundle complex in the upper synascidiate region serve the ovule. Up to 13 large vascular traces from the gynoecium, more or less equal in shape, rearrange into a ring-shaped stele at the base of the flower. Tanniferous tissue is dominant in the mesophyll of the stigmas, at the base and mid-height of the styles (Fig. 47), and is surrounding the openings of the septal nectary. Cells with oxalate raphides are present at the base and mid-height of the styles and towards the top of the ovaries.

\section{Calyptronoma}

The staminodial tube separates from the corolla above the base of the flower (Figs. 1, 54). Towards the apex the tube becomes a thick, swollen, calyptrate structure that falls shortly before anthesis (Figs. 48, 61). At the apex of the calyptra six short projections, representing the non-united tips of the six 


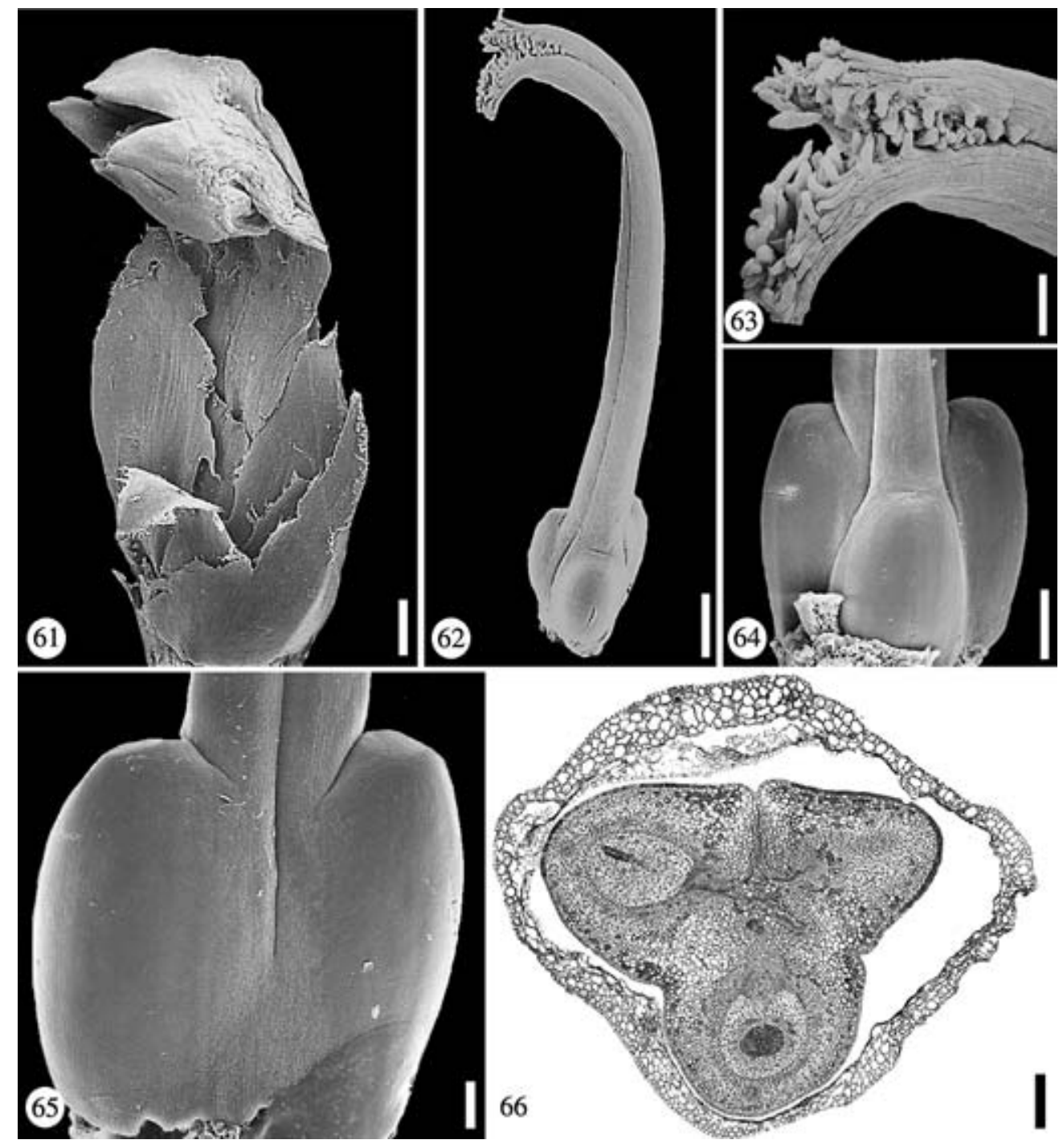

Figs. 61-66. Calyptronoma rivalis. Fig. 61. Pre-anthetic flower showing the calyptrate upper part of the sterile androecium. Scale bar $=500 \mu \mathrm{m}$. Fig. 62. Gynoecium in late bud. Scale bar $=500 \mu \mathrm{m}$. Fig. 63. Stigmas, showing the large abaxial branch. Scale bar $=200 \mu \mathrm{m}$. Fig. 64. Abaxial view of ovaries, note the reduced size of the abaxial ovary. Scale bar $=400 \mu \mathrm{m}$. Fig. 65. Adaxial view of ovaries. Scale bar $=200 \mu \mathrm{m}$. Fig. 66. TS of ovaries (transition between apocarpous and synascidiate zone); corolla and sterile androecium are congenitally fused. Scale bar $=200 \mu \mathrm{m}$

staminodes, are present. The staminodial tube contains a parenchymatous mesophyll, but at the level of the abscission zone of the calyptra, the tube is compressed, with collapsed tissue. The calyptra is formed by thickening of the abaxial region of the staminodial tube (Figs. 48, 49). Each staminode is served by one vascular strand (Figs. 48-57). Tanniferous tissue surrounds these vascular bundles and is especially concentrated around the apical opening of the calyptrate region of the staminodial tube. A few cells with oxalate raphides are present throughout the calyptrate region.

At the base the carpels are congenitally united and, particularly the abaxial carpel, partially fused with the staminodial tube (Fig. 58). The three ovaries are more or less 

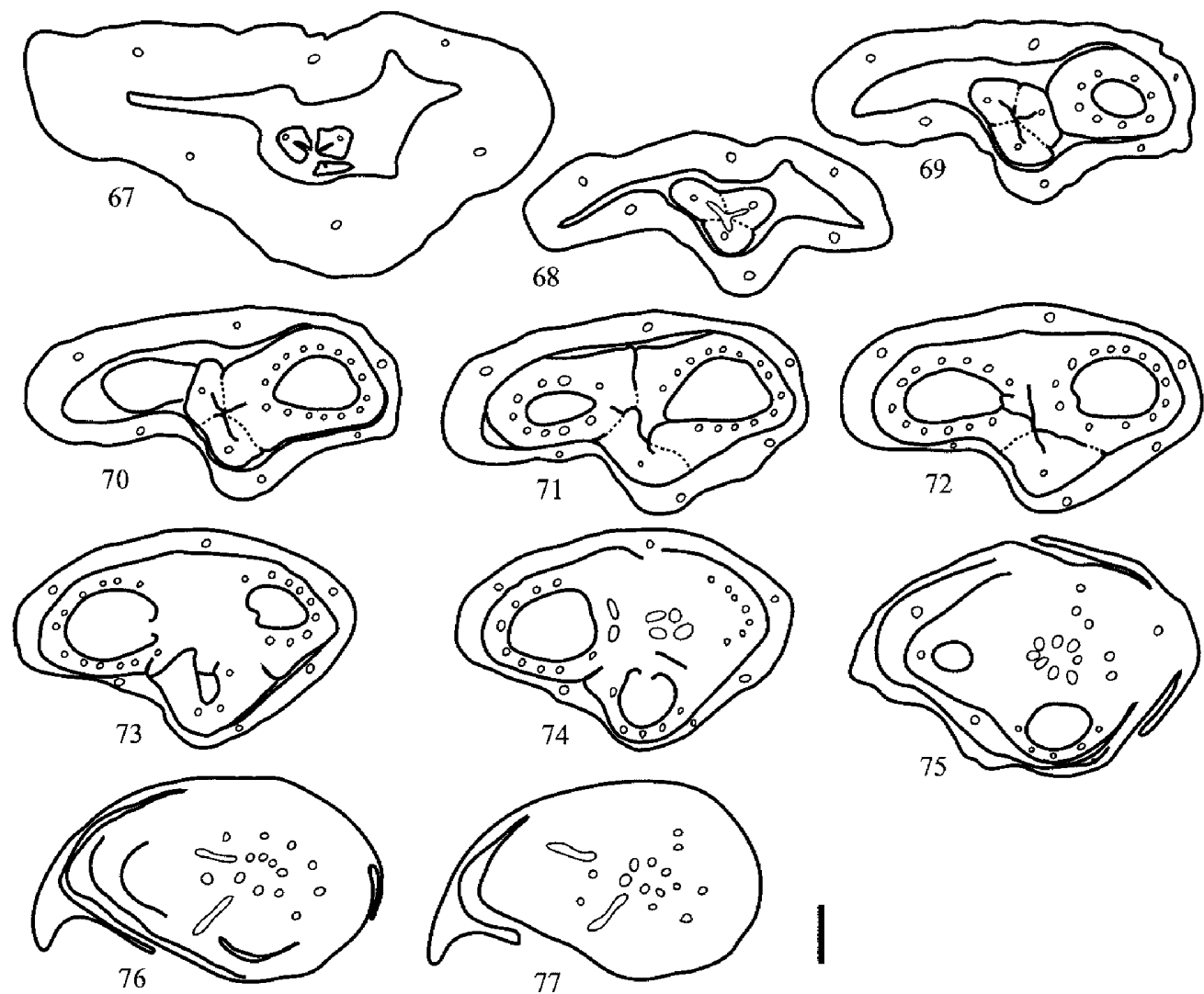

Figs. 67-77. Calyptrogyne costatifrons. Floral bud, TS series. Fig. 67. Level of free carpels (stigmas) and congenitally united bulged-out staminodes. Figs. 68-69. Apocarpous styles; carpel flanks postgenitally united (dotted lines). Figs. 70-72. Apocarpous zone of ovaries above level of placentae (postgenital union of carpels shown with dotted lines); zone with septal nectary. Figs. 73-75. Synascidiate zone at level of placentae and below. Figs. 76-77. Floral base; corolla, androecium and gynoecium are congenitally fused. Scale bar $=200 \mu \mathrm{m}$

equal in size (Figs. 55-57), and all have a well-developed ovule. The stigmatic branches are either the same size or the branch of the abaxial carpel is larger than the stigmatic branches of the adaxial carpels (Fig. 63). Unicellular papillae cover the ventral surface of the stigmatic branches. The stigmatic branches begin to spread while still in the calyptra and they spread fully once the calyptra has fallen. The styles appear to be lateral (Figs. 62, 64, 65). The carpels begin to separate from each other mainly from the center to the periphery of the syncarpous zone. No central protrusion is present between them. The ovule is attached at mid-height of the ovary (Fig. 1). The funiculus shows a papillate surface on the side that is turned away from the micropyle. The nectary forms a simple slit between the two adaxial carpels at mid-height of the ovaries (Fig. 66), but three slits farther up. The openings of the nectary are towards the top of the ovaries.

Up to four lateral procambial strands on each side of the carpel extend from the top to mid-height of the ovary and merge into two to three lateral bundles towards the base of the ovary. Some of these lateral strands connect with the ventral bundles at the base of the ovary (Figs. 48-59). Up to six large vascular traces from the gynoecium, more or less equal in shape, rearrange into a ring-shaped stele at the base of the flower. A few tanniferous cells surround the vascular 


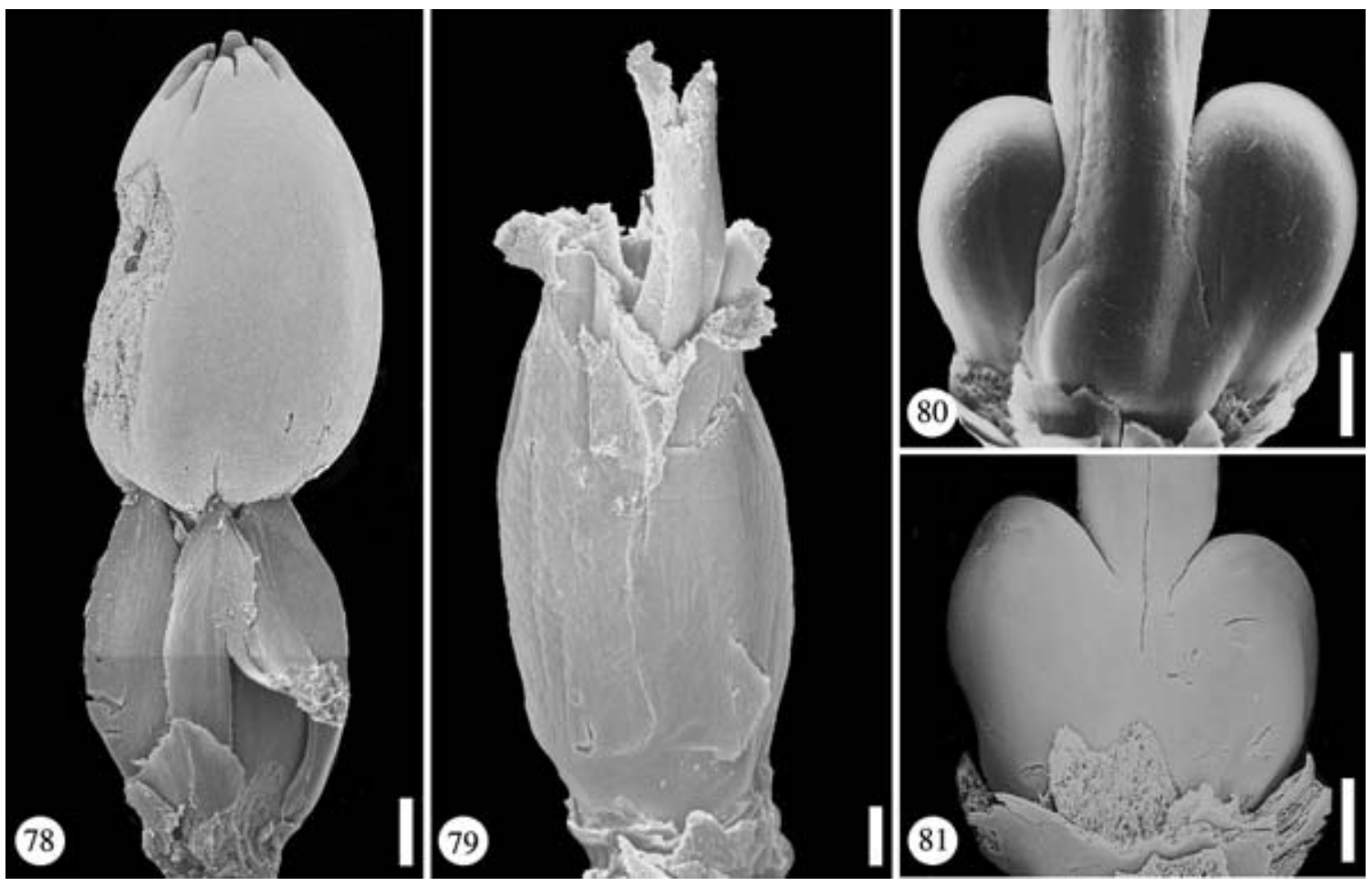

Figs. 78-81. Calyptrogyne costatifrons. Fig. 78. Pre-anthetic flower showing the calyptrate upper part of the sterile androecium. Scale bar $=500 \mu \mathrm{m}$. Fig. 79. Anthetic flower in which the calyptrate upper part of the sterile androecium has fallen. Scale bar $=300 \mu \mathrm{m}$. Fig. 80. Abaxial view of lower gynoecium, note the extreme reduction of the abaxial ovary. Scale bar $=400 \mu \mathrm{m}$. Fig. 81. Adaxial view of lower gynoecium. Scale $\operatorname{bar}=400 \mu \mathrm{m}$

bundles at the apex of the stigmatic branches, the styles, and throughout the ovaries (Fig. 66). Cells with oxalate raphides are lacking in the gynoecium.

\section{Calyptrogyne}

The staminodial tube separates from the corolla at the base of the flower (Calyptrogyne costatifrons) (Figs. 1, 75) or slightly above it (C. ghiesbreghtiana) (Figs. 1, 87). Six slits from the inner side are present at mid-height of the tube (C. ghiesbreghtiana) (Fig. 99). Towards the apex the tube forms a thick, swollen and calyptrate part (Figs. 67, 78, 82, 95), which falls off shortly before anthesis (Fig. 79). On top of the calyptra six short projections, representing the non-united tips of the six staminodes, are present (Figs. 78, 95). The abscission zone at the base of the calyptra, particularly towards the abaxial region, is formed by compressed tissue. Irregular protrusions in the inner surface of the staminodial tube are present in $C$. ghiesbreghtiana (Fig. 100). Tanniferous tissue is nearly absent (C. costatifrons) or is present in the calyptrate region of the staminodial tube, especially surrounding the six staminodial vascular bundles, which reach the six apical tips (C. ghiesbreghtiana). Cells with oxalate raphides concentrate towards the outer epidermis of the staminodial tube, at the base and mid-height, and are almost lacking in the calyptrate region.

The gynoecium is tricarpellate (Figs. 80, 96), but in one of two collections of Calyptrogyne ghiesbreghtiana (Murray 01-BH) studied, all female flowers had only two carpels (Fig. 104). In tricarpellate gynoecia the two 


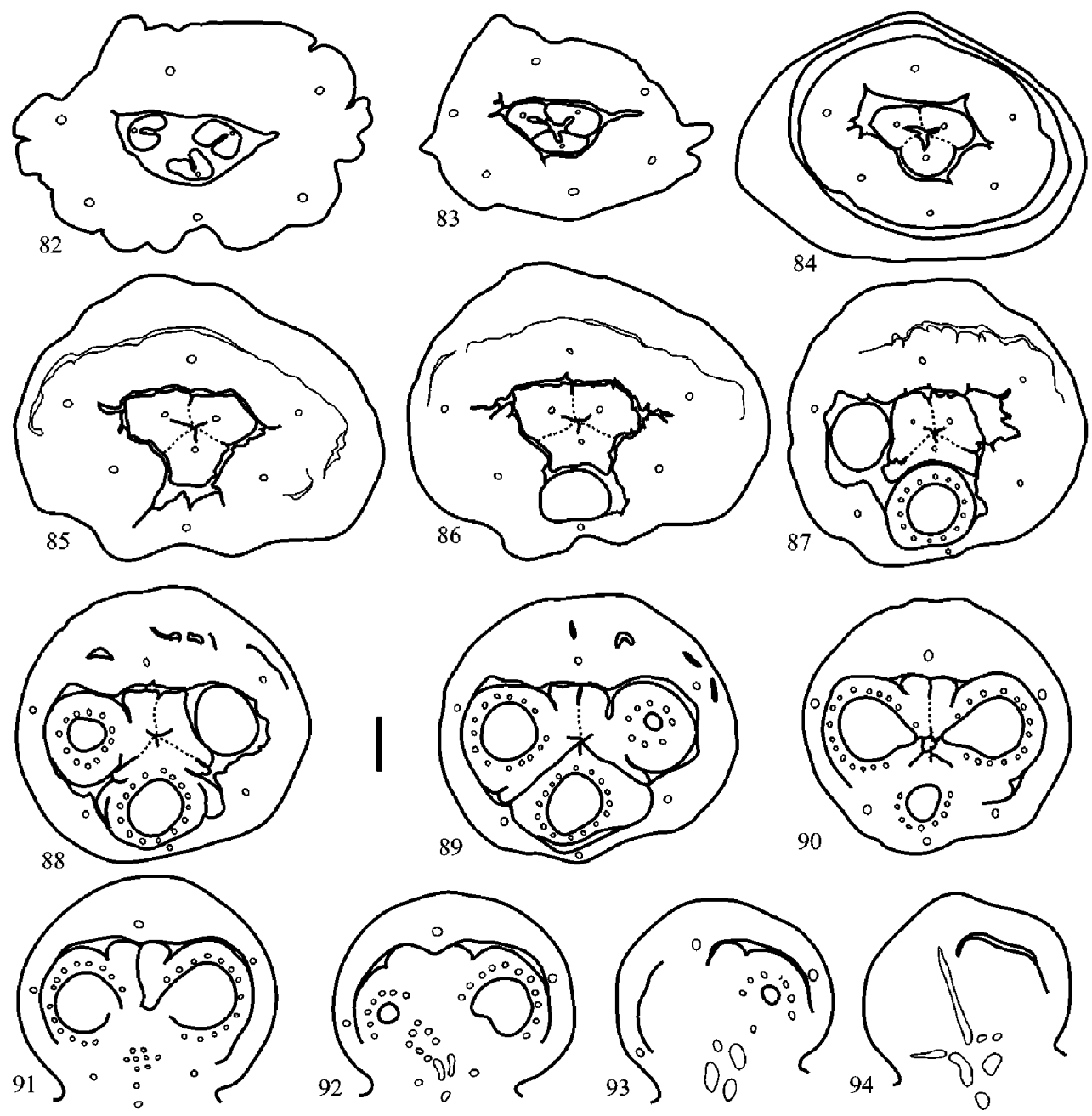

Figs. 82-94. Calyptrogyne ghiesbreghtiana. Floral bud, TS series. Fig. 82. Level of free carpels (stigmas) and congenitally united bulged-out staminodes. Figs. 83-87. Apocarpous styles; carpel flanks postgenitally united (dotted lines); congenitally united staminodes separating from the corolla. Figs. 88-90. Apocarpous zone of ovaries above level of placentae; carpel flanks are partially postgenitally united (dotted lines), septal nectary and central protrusion between carpels. Figs. 91-92. Synascidiate zone at level of placentae. Figs. 93-94. Floral base; calyx, corolla, androecium and gynoecium are congenitally fused. Scale bar $=200 \mu \mathrm{m}$

adaxial ovaries are more or less equal (C. ghiesbreghtiana) (Figs. 97, 102) or unequal in size (C. costatifrons) (Fig. 81). In C. costatifrons the abaxial ovary is conspicuously smaller than the adaxial ones (Figs. 72, 80). All carpels have a well-developed ovule (Figs. 87, 91). The stigmatic branches are unequal in length, the abaxial one being shorter than adaxial ones (Figs. 79, 96). The stigmatic branches are connivent while still enclosed by the calyptrate region of the staminodial tube and become completely reflexed at anthesis once the calyptra has fallen. Unicellular papillae cover the ventral surface of the stigmatic branches (Fig. 96). The styles appear to be lateral (Figs. 81, 97), or the abaxial one almost apical (C. costatifrons) (Fig. 80). The dorsal surface of the styles is smooth (C. costatifrons) or has irregular protrusions from the base to mid-height (C. ghiesbreghtiana) (Figs. 96, 97), which consist of large-celled, highly vacuolated tissue (Figs. 100, 101). The carpels begin to 


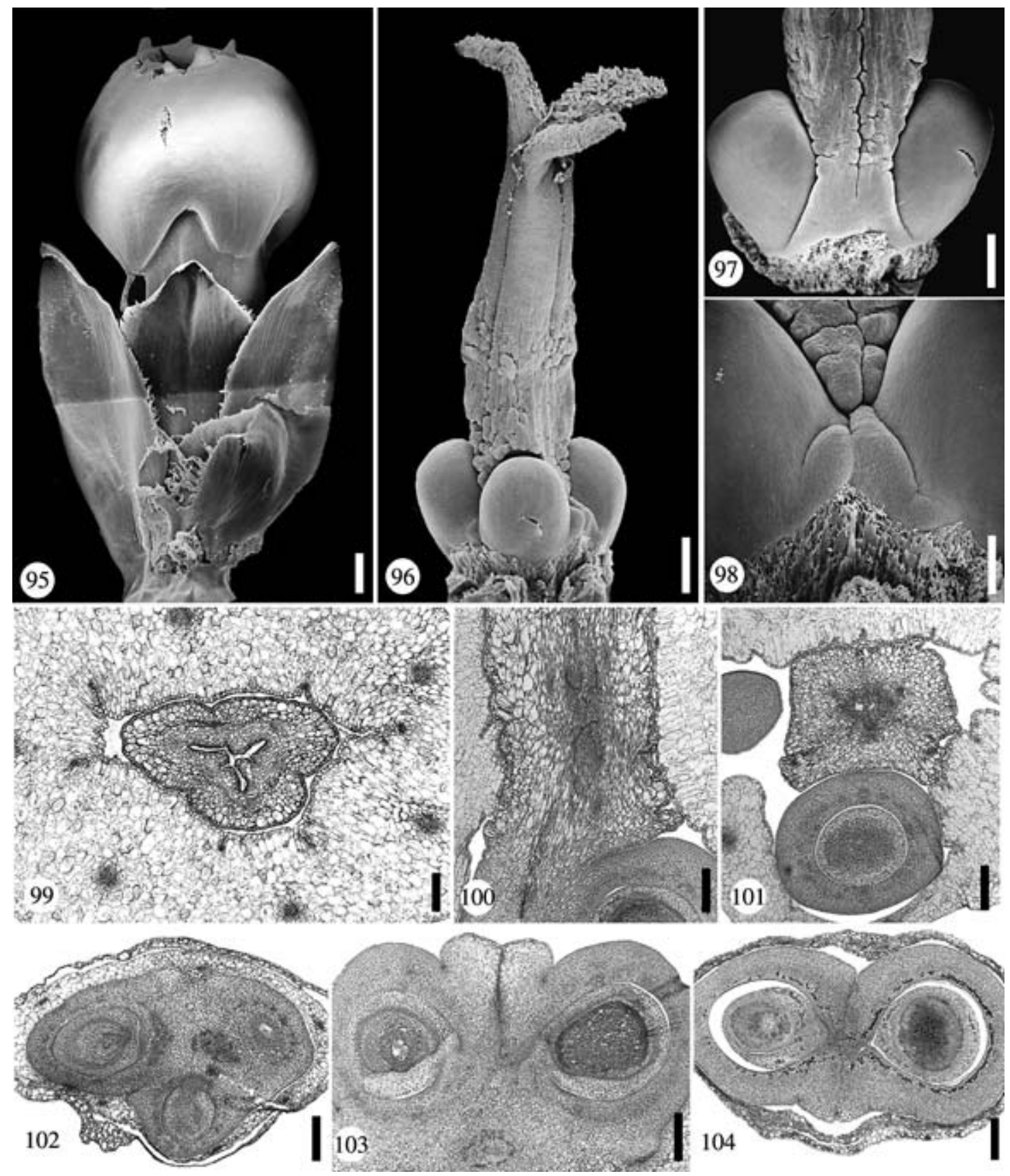

Figs. 95-104. Calyptrogyne ghiesbreghtiana. Fig. 95. Pre-anthetic flower showing the calyptrate upper part of the sterile androecium. Scale bar $=500 \mu \mathrm{m}$. Fig. 96. Gynoecium at anthesis; the styles show irregular protrusions towards the base. Scale bar $=500 \mu \mathrm{m}$. Fig. 97. Adaxial view of lower gynoecium showing the irregular protrusions at the base of the styles. Scale bar $=400 \mu \mathrm{m}$. Fig. 98. Overgrowth between the abaxial ovary and one of the adaxial ovaries. Scale $b a r=200 \mu \mathrm{m}$. Fig. 99. TS of postgenitally united styles and congenitally united staminodes. Scale bar $=200 \mu \mathrm{m}$. Fig. 100. LS of postgenitally united styles (base) and staminodial tube showing the irregular protrusions. Scale bar $=300 \mu \mathrm{m}$. Fig. 101. TS of styles and abaxial ovary. Scale bar $=300 \mu \mathrm{m}$. Fig. 102. TS of ovaries (synascidiate zone). Scale bar $=300 \mu \mathrm{m}$. Fig. 103. TS of adaxial ovaries showing one of the openings of the septal nectary. Scale bar $=300 \mu \mathrm{m}$. Fig. 104. TS of flower with bicarpellate gynoecium. Scale bar $=300 \mu \mathrm{m}$ 
separate from each other either from the periphery or the center of the syncarpous zone (Figs. 73, 91). A central protrusion is present between the three carpels; it extends from midheight to the top of the ovaries, and is secretory. The ovule is either basal and ascendent $(C$. ghiesbreghtiana) or attached at midheight of the ovary (C. costatifrons) (Fig. 1). The base of the funiculus is strongly papillate. A ventral outgrowth of the locule wall, which points toward the micropyle, may represent a short obturator. In $C$. ghiesbreghtiana the funiculus and the micropyle are not placed exactly in the same plane; the funiculus seems to be slightly bent toward one of the flanks of the ovary wall. The nectary forms a simple slit between the two adaxial carpels at mid-height of the ovaries (Figs. 90, 103) and becomes triradiate higher up. Openings of the nectary are at different levels of the ovaries. The opening between the adaxial carpels is towards the base (C. ghiesbreghtiana) (Fig. 91) or top of the ovaries (C. costatifrons) (Fig. 71); those between the abaxial carpel and the two adaxial carpels are at mid-height of the ovaries. In C. ghiesbreghtiana the openings are sometimes between two conspicuous outgrowths formed by the adaxial ovaries (Figs. 91, 98) or between the abaxial ovary and one of the adaxial ovaries.

Six to seven procambial strands, on each side of the carpel, extend from the top to midheight of the ovary and merge into three to four lateral bundles towards the base of the ovary (Figs. 70-75). Some of the lateral bundles connect with the dorsal bundle towards the top of the ovary in an upward direction (C. costatifrons) and also with the ventral bundles at mid-height and at the base of the ovary. Up to six (C. ghiesbreghtiana) or 11 (C. costatifrons) large vascular traces, more or less equal in size, are arranged into a ring-shaped stele at the base of the flower. Tanniferous tissue is restricted to the top of the stigmatic branches, the dorsal surface of the carpels, particularly at the upper level of the locules, and in the integument and nucellus (Figs. 103, 104). Cells with oxalate raphides are absent in the gynoecium (C. ghiesbreghtiana) or scarcely present in the dorsal hypodermis at the base of the styles (C. costatifrons).

\section{Asterogyne}

The staminodial tube separates from the corolla in the upper half of the corolla, near the base of the free parts of the staminodes (Fig. 1). The upper part of the tube is slightly swollen and ends with six (Asterogyne martiana) (Fig. 105), seven to eight (A. yaracuyense) (Fig. 146), eight to nine (A. ramosa), or 21 (A. spicata) (Fig. 126) free parts, which are connivent in bud (Figs. 118, 138, 157) and spreading at anthesis (Fig. 117). Separation of these free parts begins as slits from the inner surface of the staminodial tube (Figs. 128, 148). The epidermis of the free parts of the staminodes is papillate in A. spicata (Figs. 141, 142), but not in the other species. Some of the free parts of the staminodes show possibly secretory slits, which differentiate from the ventral sides ( $A$. spicata, $A$. yaracuyense) (Figs. 126, 138, 141, 142). Tanniferous tissue is concentrated at the apex of the staminodes or is almost absent (A. ramosa). Cells with oxalate raphides are present in the mesophyll of the staminodial tube.

The two adaxial carpels are of about the same size; the adaxial one has a smaller ovary and a shorter stigma (Figs. 122, 123, 139, 140). However, all carpels have a well-developed ovule (Figs. 124, 144, 160). The stigmas are exserted from the free parts of the staminodes at anthesis (Fig. 117). The dorsal side of the stigmatic branches is flat (Asterogyne martiana) or rounded (A. ramosa, A. spicata, A. yaracuyense). Unicellular papillae cover the ventral side of the stigmatic branches (Fig. 120). The styles appear to be lateral (Figs. 139, 158). In A. martiana the dorsal side of the styles has irregular, large-celled protrusions up to midheight (Figs. 119, 121). The carpels separate from each other beginning at the periphery of the syncarpous zone (A. spicata) or in the center (A. martiana, A.ramosa, A. yaracuyense) (Figs. 114, 154). A central protrusion is present 


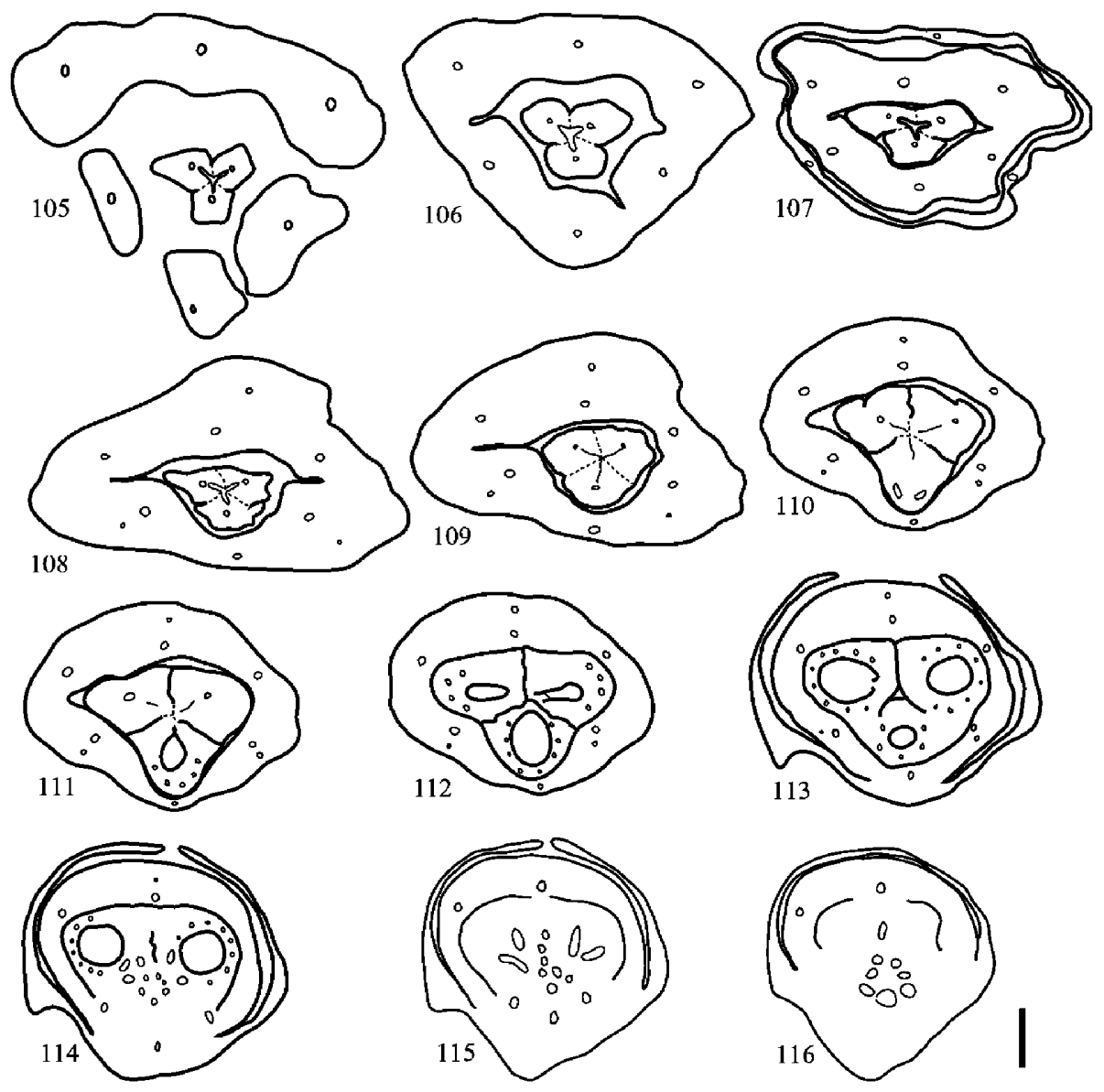

Figs. 105-116. Asterogyne martiana. Floral bud, TS series. Figs. 105-110. Apocarpous styles; carpel flanks postgenitally united (dotted lines); congenitally united staminodes separating from the corolla. Figs. 111-112. Apocarpous zone of ovaries above level of placentae; zone with septal nectary. Figs. 113-114. Synascidiate zone at level of placentae and below, zone with lower septal nectary and central protrusion between carpels. Figs. 115-116. Floral base; calyx, corolla, androecium and gynoecium are congenitally fused. Scale bar $=200 \mu \mathrm{m}$

between the three carpels, it extends shortly above mid-height of the ovaries and is secretory (Figs. 113, 124). The ovule is attached at midheight of the ovary (Fig. 1). The nectary forms a simple slit between the bases of the adaxial carpels (A. martiana, A. spicata, A. yaracuyense) or at mid-height of the ovaries ( $A$. ramo$s a)$. All three openings of the nectary are towards the top of the ovaries ( $A$. ramosa, A. spicata) (Fig. 130), or that between the adaxial carpels is at the base of the ovaries (A. martiana, A. yaracuyense) (Figs. 113, 153).

In $A$. spicata, one lateral bundle on each side of the ventral slit extends from the base of the stigmatic branch to the base of the ovary (Figs. 126-135, 143). Either two to three (A. martiana), four to five (A. ramosa, A. spicata), or six to seven (A. yaracuyense) procambial strands on each side of the carpel extend from the top to the base of the ovary. Some of the lateral procambial strands connect with the ventral bundle at the base of the ovary (A. martiana, A. yaracuyense) or merge into three to four lateral bundles downwards (A. ramosa, A. spicata). Between seven and 13 large vascular traces from the gynoecium, more or less equal in shape, rearrange into a ring-shaped stele at the base of the flower. 


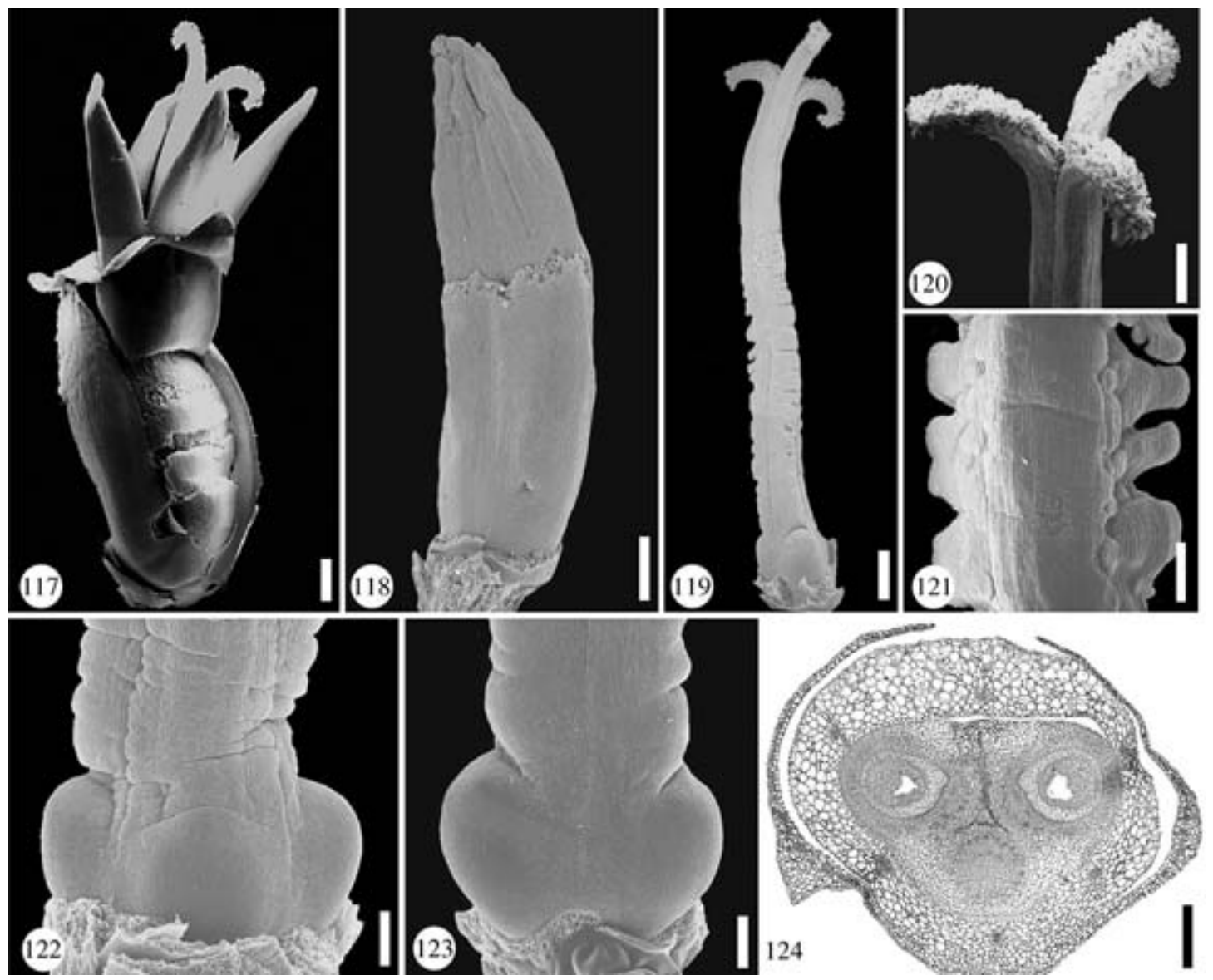

Figs. 117-124. Asterogyne martiana. Fig. 117. Flower at anthesis. Scale bar $=500 \mu \mathrm{m}$. Fig. 118. Flower in late bud (calyx and upper part of corolla removed); the free parts of the staminodes are tightly connivent. Scale bar $=450 \mu \mathrm{m}$. Fig. 119. Gynoecium at anthesis, note the irregular protrusions up to mid-length of the styles. Scale bar $=500 \mu \mathrm{m}$. Fig. 120. Stigmas at anthesis showing the exposed papillae. Scale bar $=1 \mathrm{~mm}$. Fig. 121. Irregular protrusions of the styles (mid-length). Scale bar $=400 \mu \mathrm{m}$. Fig. 122. Abaxial view of lower gynoecium, note the reduced size of the abaxial ovary. Scale bar $=200 \mu \mathrm{m}$. Fig. 123. Adaxial view of lower gynoecium. Scale bar $=200 \mu \mathrm{m}$. Fig. 124. TS of flower showing septal nectary and central protrusion between the three carpels; the sterile androecium is partially congenitally fused with the gynoecium. Scale bar $=300 \mu \mathrm{m}$

Tanniferous tissue occurs throughout the gynoecium, especially concentrated at the apex of the stigmatic branches, towards the top of the ovaries, and particularly surrounding the openings of the septal nectary. Cells with oxalate raphides are absent in the gynoecium.

\section{Geonoma}

The staminodes are united into a tube, but their upper part is differentiated in various ways (Figs. 1, 182-187). The tube separates from the corolla at the base of the flower (Fig. 1). Six vascular traces are present in the staminodial tube at the level of the ovary top (e.g. Geonoma interrupta, G. simplicifrons) (Figs. 162-166). Tanniferous tissue is present along all the tube or concentrated only towards the top ( $G$. linearis). Cells with oxalate raphides are present at the base and mid-height of the tube (e.g. G. atrovirens, G. baculifera, G. congesta, G. irena, G. macrostachys). 


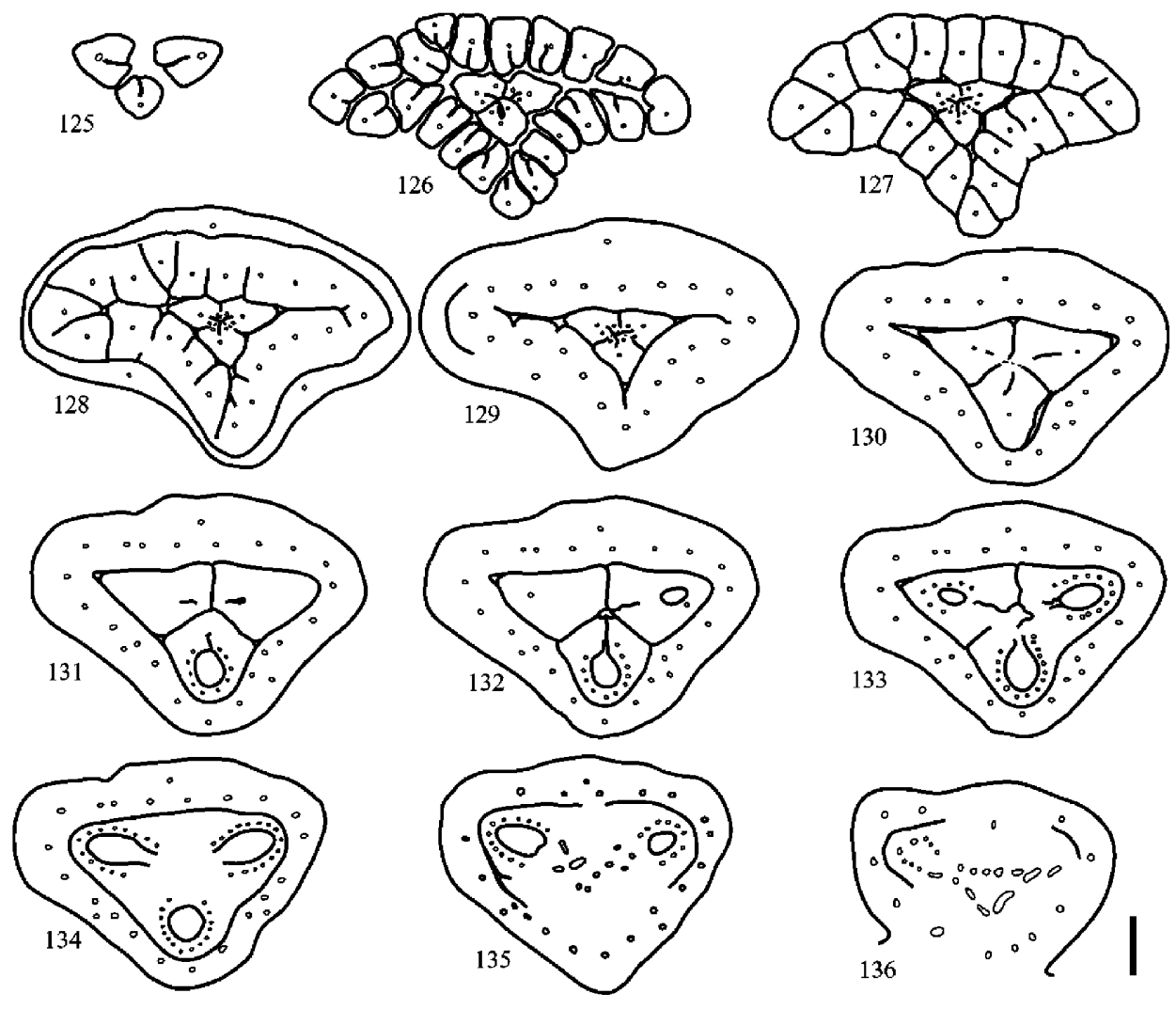

Figs. 125-136. Asterogyne spicata. Floral bud, TS series. Fig. 125. Level of apocarpous stigmas. Figs. 126-129. Symplicate zone of styles; carpel flanks partially postgenitally united (dotted lines). Figs. 130-133. Apocarpous zone of ovaries above level of placentae; zone with septal nectary and central protuberance between the carpels. Figs. 134-135. Synascidiate zone at level of placentae and below in 135; androecium and gynoecium are partially congenitally fused. Fig. 136. Floral base; calyx, corolla, androecium and gynoecium are congenitally fused. Scale $b a r=200 \mu \mathrm{m}$

Morphological diversity of the free staminodial tips has been, at least externally, described by Spruce (1871), Burret (1930) and Wessels Boer (1968) in Geonoma. In the first two studies, two types of tips were observed (truncate to dentate, and lobed), in the latter five types (crenulate, slightly crenulate, truncate, shortly dentate, and digitately lobed). In our study we found that in some species the tips show intermediate forms, which are difficult to fit into these proposed categories; therefore, we distinguish only three forms: truncate, crenulate-dentate and lobed.

In the truncate form, the individual staminode tips and thus the number of staminodes, is not evident from a superficial view
(Fig. 170). In some species (e.g. G. baculifera and $G$. cuneata) the truncate androecium is apically swollen and slightly calyptrate (Figs. 174, 184, 187). The crenulate-dentate form is the most common in the material studied and the genus as a whole. Six longitudinal furrows, corresponding to the interspaces between staminodes, differentiate at the top of the tube (Figs. 183, 186). Deviations from the completely crenulate to the completely dentate apex were seen in some flowers of $G$. congesta. In the lobed form the staminodes appear as six or, less commonly, ten short free lobes (Figs. 182, 185). In bud, the lobes are connivent and enclose the stigmatic branches, at anthesis they are widely spreading. Of the ten 

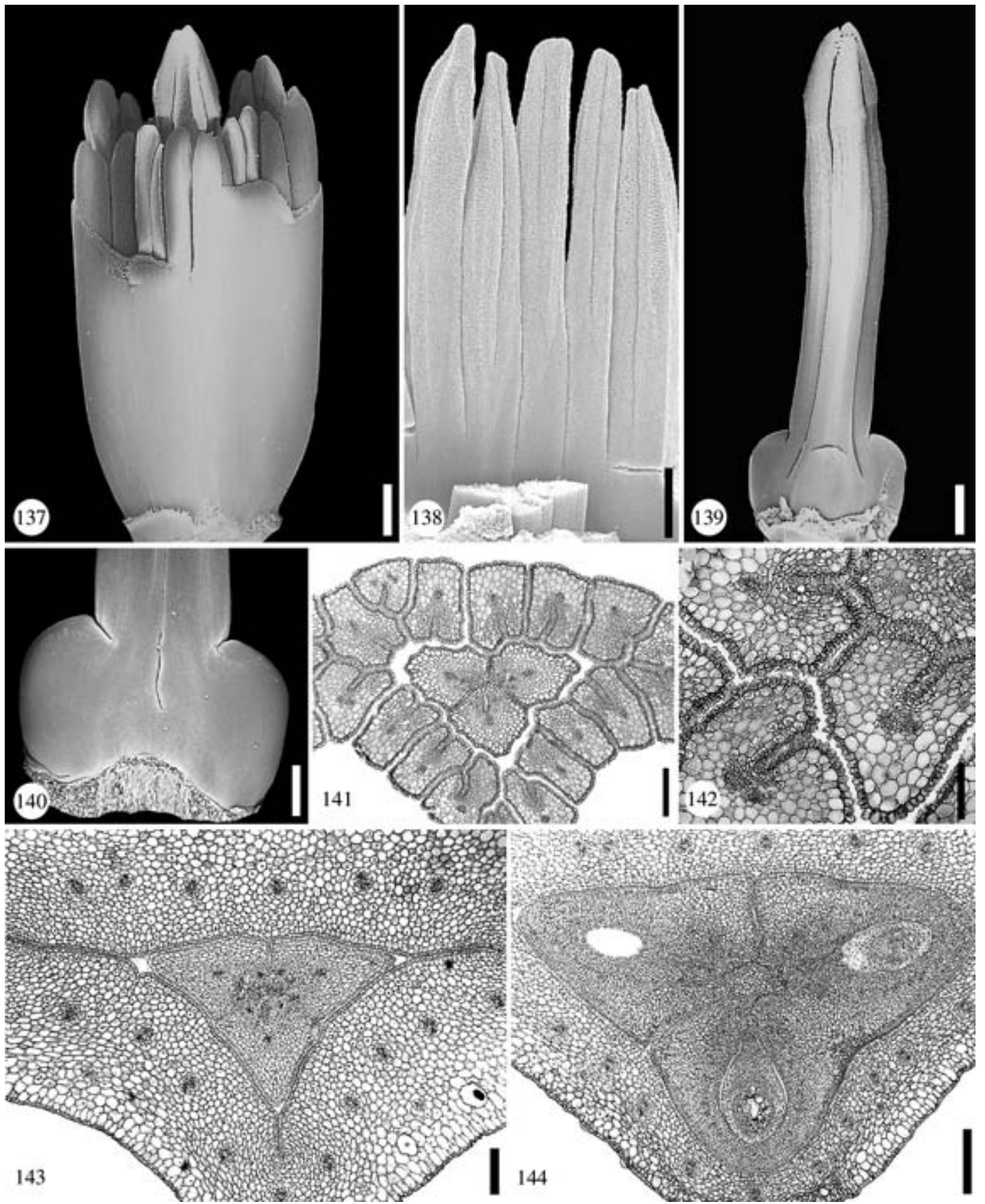

Figs. 137-144. Asterogyne spicata. Fig. 137. Pre-anthethic flower (calyx and upper part of corolla removed) showing connivent staminodes. Scale bar $=500 \mu \mathrm{m}$. Fig. 138. Ventral view of staminodes with longitudinal slits. Scale bar $=450 \mu \mathrm{m}$. Fig. 139. Gynoecium in late bud (the abaxial ovary is reduced in size). Scale bar $=500 \mu \mathrm{m}$. Fig. 140. Adaxial view of lower gynoecium. Scale bar $=400 \mu \mathrm{m}$. Fig. 141. TS of postgenitally united styles and free staminodes. Scale bar $=300 \mu \mathrm{m}$. Fig. 142. TS of free staminodes showing ventral slits and papillate epidermis. Scale bar $=150 \mu \mathrm{m}$. Fig. 143. TS of congenitally united staminodes and postgenitally united styles. Scale bar $=200 \mu \mathrm{m}$. Fig. 144. TS of androecium and gynoecium showing openings of the septal nectaries. Scale bar $=300 \mu \mathrm{m}$ 


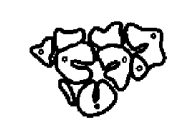

145
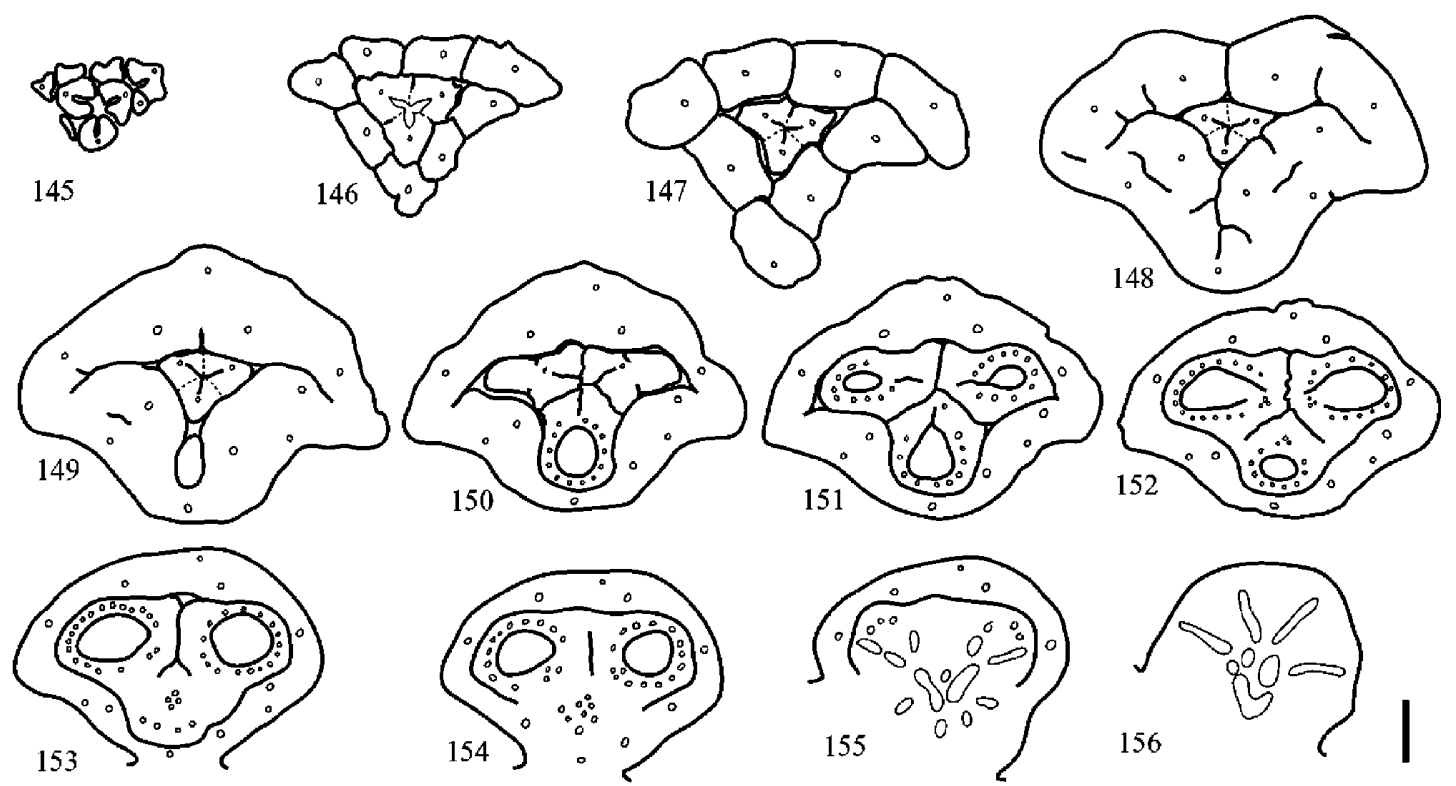

Figs. 145-156. Asterogyne yaracuyense. Floral bud, TS series. Fig. 145. Level of stigmas and free staminodes. Figs. 146-149. Apocarpous styles; carpel flanks partially postgenitally united (dotted lines); separation of corolla from androecium. Figs. 150-152. Apocarpous zone of ovaries above and at the level of placentae; zone with septal nectary. Figs. 153-154. Synascidiate zone below level of placentae; opening of the septal nectary between two adaxial carpels. Figs. 155-156. Floral base; calyx, corolla, androecium and gynoecium are congenitally fused. Scale bar $=200 \mu \mathrm{m}$

Geonoma species with a lobed form, eight have six staminodes and two (G. chococola, G. polyandra) have up to ten. In $G$. polyandra the additional staminodes seem to come about by double position of organs.

The gynoecium is tricarpellate but appears pseudomonomerous later in development, only one of the adaxial ovaries fully develops, whereas the other two remain as small knobs at the base of the gynoecium (Figs. 165, 171, 172). In Geonoma cuneata and G. interrupta one (or rarely two) sterile ovaries develop up to $3 / 4$ the size of the fertile ovary (Figs. 177178). Separation among the carpels begins in the center and proceeds to the periphery of the syncarpous zone (Figs. 167, 172). The stigmatic branches are equal in length (Figs. 169, 175). Unicellular papillae, especially large in $G$. macrostachys and G. supracostata, cover the ventral surface of the stigmatic branches (Figs. 171, 176). The style of the fertile carpel appears to be basal, and the styles of the sterile carpels appear to be apical (Fig. 171); the styles are especially long in G. congesta. A central protrusion is present between the three carpels (G. interrupta) or absent (e.g. G. cuneata, G. simplicifrons). It extends shortly above mid-height of the fertile ovary and is secretory. The sterile carpels do not contain ovules, only in $G$. cuneata, both sterile locules sometimes show aborted ovules. The ovule is basal and ascendent (Figs. 1, 173). In the ovule of a younger floral bud of $G$. maxima two integuments could be distinguished (Fig. 181). The nectary begins as a simple slit, at the base of the gynoecium, between the fertile ovary and one or two sterile ovaries. The openings of the nectary are at mid-height of the fertile ovary (Figs. 165, 179-180).

Towards the top of the ovary the mesophyll is highly vascularized. Up to ten (two to three in the sterile carpels) small and undifferentiated procambial strands are present on each side of the fertile carpel at mid-height of the ovary. The procambial strands merge into four to six vascular bundles towards the base 


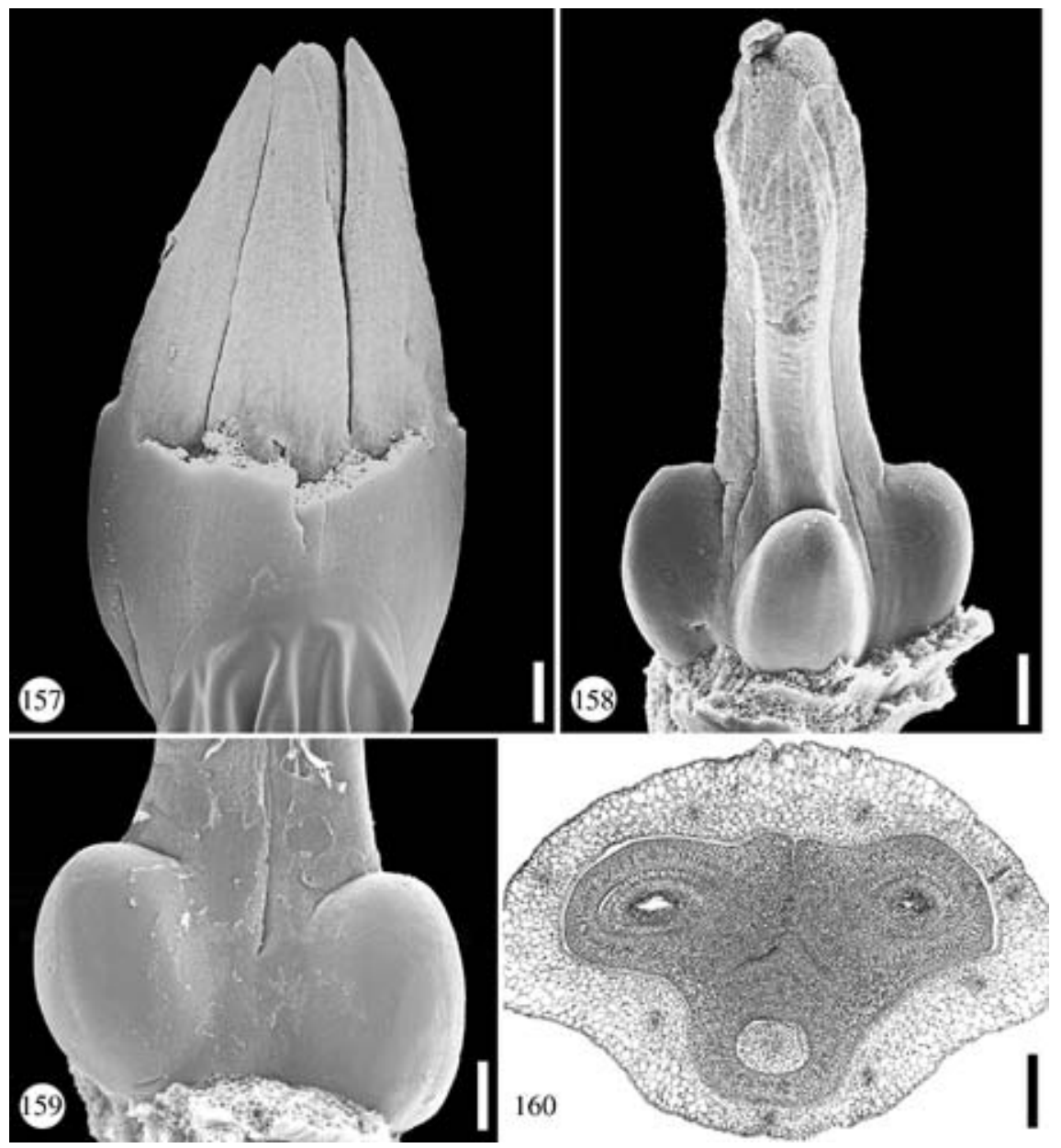

Figs. 157-160. Asterogyne yaracuyense. Fig. 157. Pre-anthethic flower (calyx and upper part of corolla removed) showing connivent staminodes. Scale bar $=500 \mu \mathrm{m}$. Fig. 158. Gynoecium in late bud. Scale bar $=500 \mu \mathrm{m}$. Fig. 159. Adaxial view of lower gynoecium. Scale bar $=400 \mu \mathrm{m}$. Fig. 160. TS of united staminodes and ovaries showing the adaxial openings of the septal nectary. Scale bar $=300 \mu \mathrm{m}$

of the ovary. Up to eleven large vascular traces from the gynoecium, more or less equal in shape, rearrange into a ring-shaped stele at the base of the flower (Figs. 161-168). Tanniferous tissue is present throughout the gynoecium, especially concentrated in styles and stigmas, ovary wall and surrounding the nectary ducts (Figs. 172, 178-181). Cells with oxalate raphides are present at mid-height and towards the top of the fertile ovary.

\section{Discussion}

Structure of the female flowers in Geonomeae. Flowers with organs variously congenitally or postgenitally united in all whorls are present in all subfamilies of Arecaceae. In Geonomeae, perianth parts are congenitally united at least at the base, the staminodes are congenitally united into a tube, and the carpels are basally congenitally united, free at mid-length and postgenitally united towards the upper part. The degree of fusion between androecium and corolla is diverse. In Asterogyne (A. martiana, Schmid, 1983), and Welfia the staminodes separate from the corolla in its upper half, at the base of the free parts of the corolla. In Pholidostachys, Calyptronoma and Calyptrogyne ghiesbreghtiana the staminodes separate from the corolla in the lower half, and in 


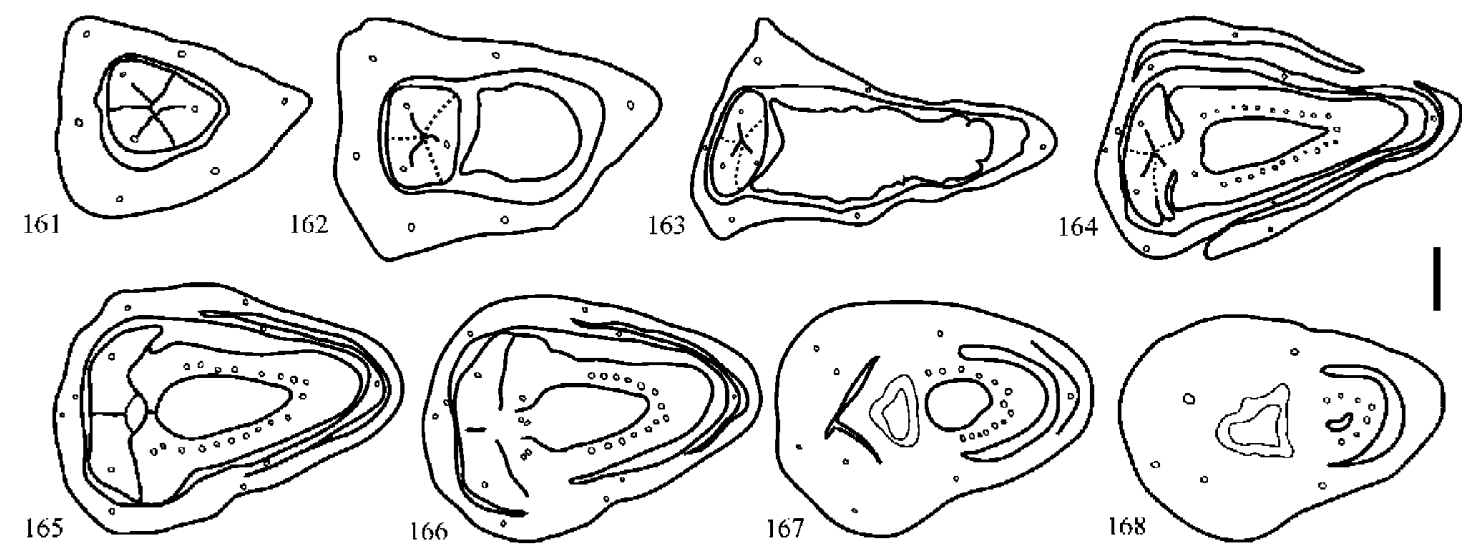

Figs. 161-168. Geonoma simplicifrons. Floral bud, TS series. Figs. 161-163. Apocarpous styles; carpel flanks postgenitally united (dotted lines); staminodes congenitally united. Figs. 164-165. Apocarpous zone of ovaries above level of placenta; zone with septal nectary and central protuberance between carpels. Figs. 166-167. Synascidiate zone at level of placenta and below; separation of carpels. Fig. 168. Floral base; perianth, androecium and gynoecium are congenitally fused. Scale bar $=200 \mu \mathrm{m}$

Calyptrogyne costatifrons and Geonoma at the base of the corolla.

A staminodial tube with a thick, bulging calyptra, which abscises at anthesis, is only present in Calyptrogyne and Calyptronoma among Arecaceae; in Calyptronoma the abscission zone at the base of the calyptra is more conspicuous than in Calyptrogyne. In Geonoma baculifera and G. cuneata the upper part of the staminodial tube is also thick and bulging, but without an abscission zone at its base. In Calyptronoma the free parts of the staminodes are longer than in Calyptrogyne but shorter than in some Geonoma species (e.g. G. polyandra, G. supracostata). In three of the six genera there are constantly six staminodes; but in Welfia, Asterogyne (except for A. martiana) and a few Geonoma species the number is increased; staminodial number becomes highly labile in androecia with 20 staminodes or more. In all species studied the number of staminodes was equal or lower than the number of fertile stamens, except for Pholidostachys, in which there were six to seven, rarely eight, staminodes (Uhl and Dransfield 1987), but only six fertile stamens. Production of secretion at the surface of the free staminode tips was observed in Asterogyne martiana by Schmid (1970a). However, in our material the staminodes did not show an apparent secretory tissue. Only in A. spicata a potentially secretory epidermis differentiates in the free parts of the staminodes, suggesting that the presence of secretory tissues in the staminodes may be variable within the genus.

The tricarpellate gynoecium of Geonomeae is at least basally syncarpous. The two adaxial ovaries are almost equal in size and shape, and the abaxial ovary is slightly smaller. Only in Geonoma is the gynoecium pseudomonomerous (Eckardt 1937, Uhl and Moore 1971, Stauffer et al. 2002). In general, the term pseudomonomery is used in gynoecia that have a monomerous appearance but are composed of more than one carpel of which only one is well developed. Eckardt (1937) listed pseudomonomery for species of 42 angiosperm families, among them ten of monocotyledons (eleven, according to APG 1998, APG II 2003), in which it is derived from a dimerous (Araceae, Sparganiaceae, Stemonaceae, Typhaceae), or a trimerous or pleiomerous gynoecium (Arecaceae, Colchicaceae, Marantaceae, Poaceae, Pontederiaceae, Restionaceae, Smilacaceae) (see also Ronse Decraene and Smets 1998). The degree of reduction of the sterile carpels varies from still clearly developed, as in most palms or Restionaceae (Ronse Decraene 

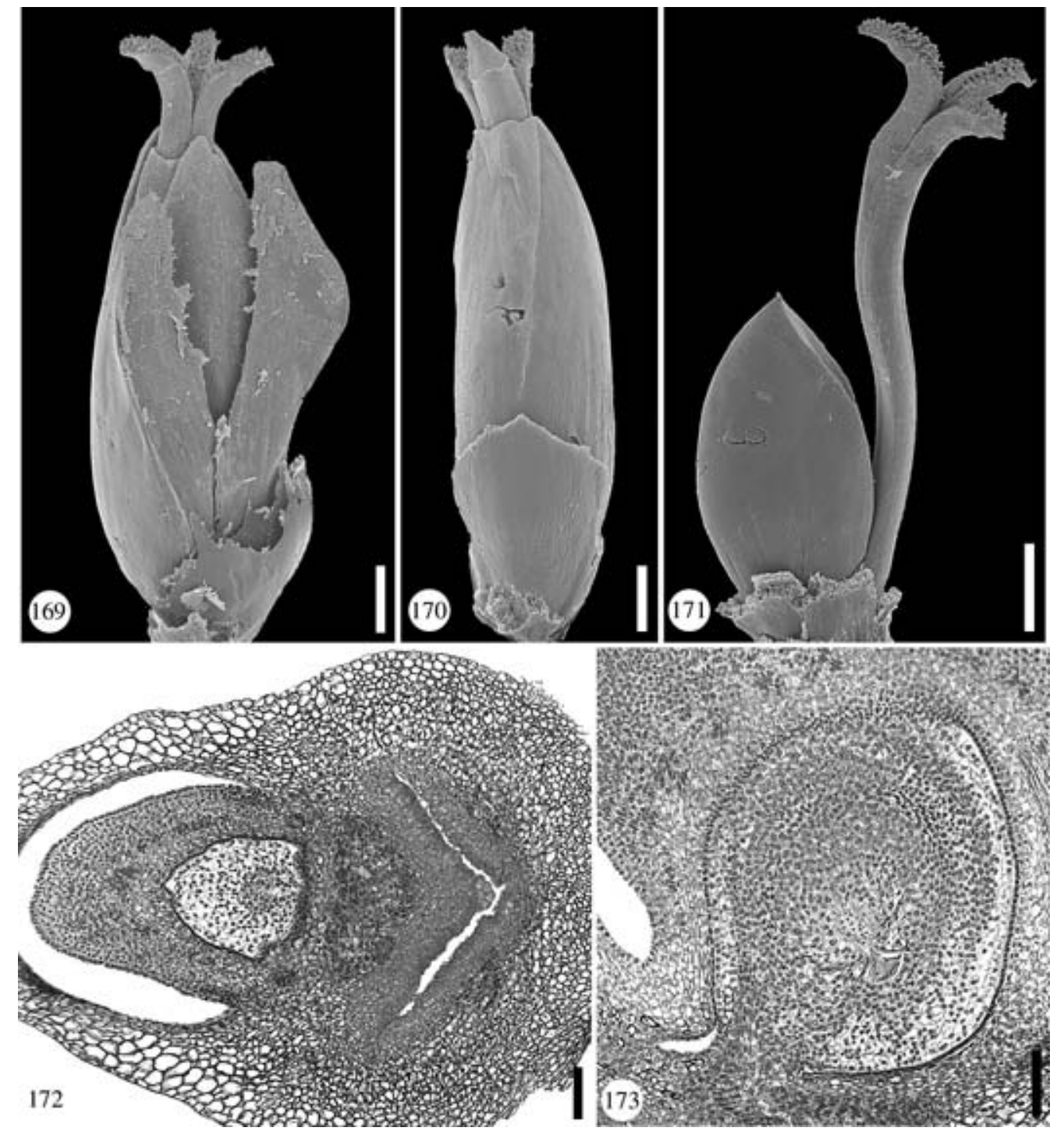

Figs. 169-173. Geonoma simplicifrons. Fig. 169. Flower at anthesis. Scale bar $=500 \mu \mathrm{m}$. Fig. 170. Pre-anthetic flower (perianth removed), note the truncate upper part of the sterile androecium. Scale bar $=450 \mu \mathrm{m}$. Fig. 171. Gynoecium at anthesis showing the apparently basifixed styles and the strongly bulged fertile ovary. Scale bar $=500 \mu \mathrm{m}$. Fig. 172. TS of flower at the base of the gynoecium showing lower part of the septal nectary. Scale bar $=100 \mu \mathrm{m}$. Fig. 173. Erect, anatropous ovule. Scale bar $=100 \mu \mathrm{m}$

et al. 2001, 2002), to almost nothing, as, e.g. in Typhaceae (Müller-Doblies 1970) or Araceae (Barabé et al. 1987). The mode of separation of the carpels from each other above the syncarpous zone seems to be variable in some of the genera studied. It is either from the center to the periphery (Calyptrogyne ghiesbreghtiana, Asterogyne p.p., Geonoma), from the periphery to the center (Asterogyne spicata), or either way (Pholidostachys, Welfia, Calyptrogyne costatifrons).

The stigmatic branch of the abaxial (mostly reduced) carpel is almost always the smallest one. However, in Calyptronoma rivalis, the reverse is the case, the abaxial branch is unusually elongate and almost protrudes out of the calyptrate region of the androecium, whereas the adaxial stigmatic branches are 


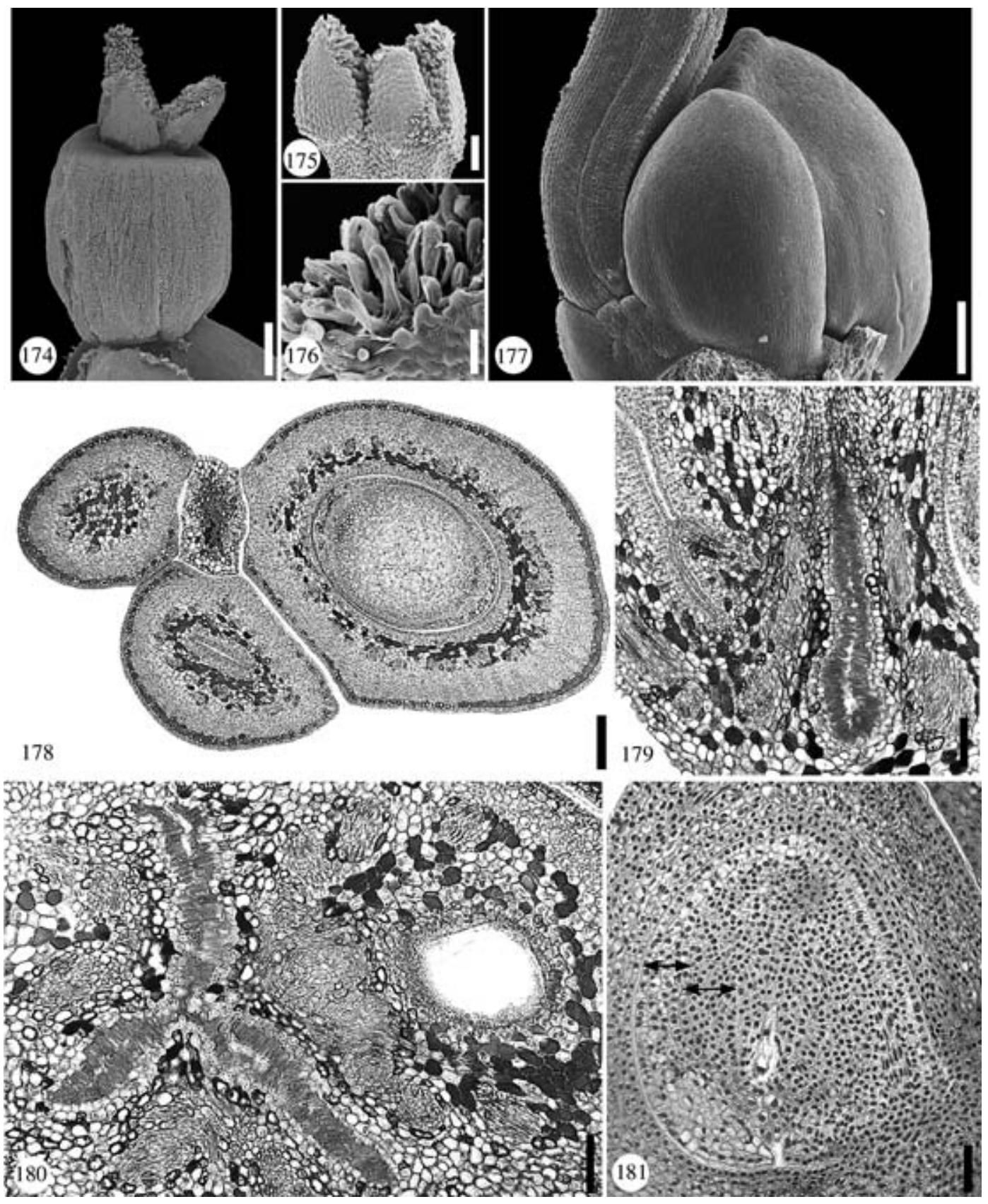

Figs. 174-180. Geonoma cuneata; 181. G. maxima. Fig. 174. Calyptrate sterile androecium and stigmas. Scale bar $=400 \mu \mathrm{m}$. Fig. 175. Pre-anthetic stigmas. Scale bar $=125 \mu \mathrm{m}$. Fig. 176. Stigmatic papillae. Scale bar $=30 \mu \mathrm{m}$. Fig. 177. Lower gynoecium showing the fertile ovary and further development of one of the two sterile ovaries, and the postgenitally united styles. Scale bar $=200 \mu \mathrm{m}$. Fig. 178. TS of gynoecium showing the bulged-out fertile ovary and two further developed sterile ovaries. Scale bar $=200 \mu \mathrm{m}$. Fig. 179. LS of septal nectary showing the secretory epithelium. Scale bar $=100 \mu \mathrm{m}$. Fig. 180. TS of base of ovaries (synascidiate zone) showing the base of the septal nectary. Scale bar $=100 \mu \mathrm{m}$. Fig. 181. LS of ovule in which two integuments and the nucellus can be distinguished; arrows showing the outer and the inner integument. Scale bar $=50 \mu \mathrm{m}$ 

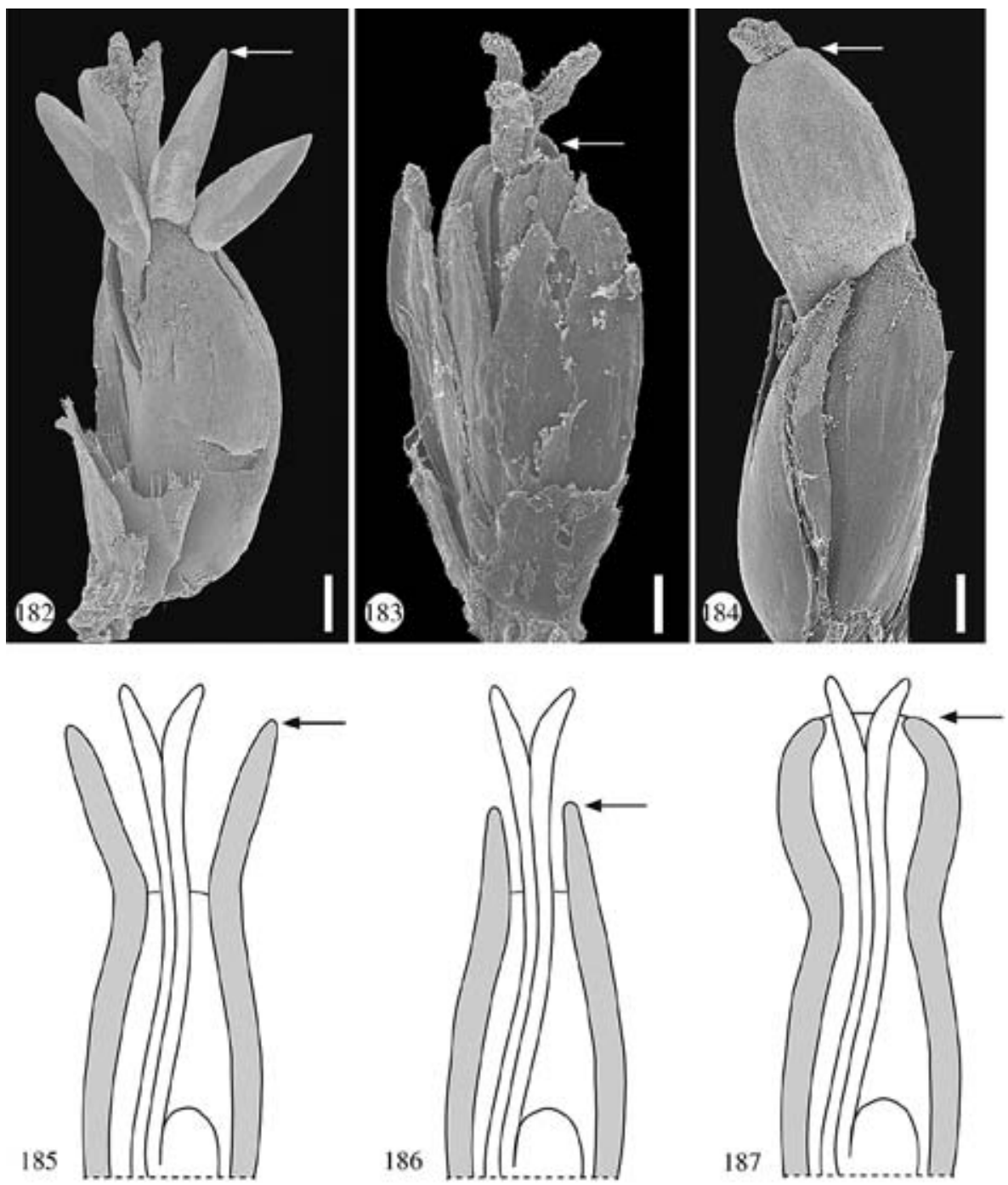

Figs. 182-187. Female flowers of Geonoma. Fig. 182. Geonoma supracostata. Scale bar $=500 \mu \mathrm{m}$. Fig. 183. G. interrupta. Scale bar $=450 \mu \mathrm{m}$. Fig. 184. G. congesta. Scale bar $=500 \mu \mathrm{m}$. Figs. 185-187. Schematic LS showing diversity of upper parts of the sterile androecia. Androecium gray, top of androecium marked with arrows, upper end of united part of androecium marked with line. Fig. 185. G. supracostata. Fig. 186. G. interrupta. Fig. 187. G. congesta

shorter and remain hidden at anthesis. This early protrusion of the abaxial and receptive stigmatic branch possibly enables pollination of the flower even before the calyptra falls. Unicellular, secretory papillae cover the entire ventral surface of the stigmatic branches, but in Welfia, the large papillae, especially those surrounding the ventral slits, are multicellular. The large amounts of secretion observed on the stigmas of Geonomeae indicate that they are "wet", following the terminology of Heslop-Harrison and Shivanna (1977).

The styles appear to be lateral, apical, or (in Geonoma, that of the fertile carpel) basal, depending on the degree to which the ovary is bulged up. In Geonoma the apparent basal insertion of the style is due to the lack of expansion of the abortive ovaries (Uhl and Moore 1971, Stauffer et al. 2002); the styles look superficially free, but are postgenitally 
united along their flanks. In all Geonomeae studied, in the region of postgenital union of the styles, the PTTT of all three carpels is united into a compitum. The presence of a compitum, a centralized PTTT for all carpels of a gynoecium, by postgenital union of free carpels is not uncommon in angiosperms. It was reported from some other monocots, such as taxa of Tecophilaeaceae, Heliconiaceae, and Alliaceae (Hartl and Severin 1981), and Tofieldiaceae (Igersheim et al. 2001), and from several families of core eudicots (e.g. Endress et al. 1983).

Conspicuous irregular dorsal protrusions in the styles are present in Pholidostachys synanthera, Calyptrogyne ghiesbreghtiana and Asterogyne martiana. Schmid (1970a) mentioned that when slightly damaged the translucent stylar protrusions of Asterogyne martiana readily exude fluid, which gives a reading in a refractometer identical to that obtained for nectar sugar concentration. However, according to our study this tissue contains highly vacuolated cells and does not resemble secretory tissue.

In all species studied, the gynoecium is syncarpous, synascidiate up to mid-height of the ovaries; above the syncarpous zone the carpels separate for a short length and then postgenitally unite up to mid-height of the styles (see also Uhl 1966 for Asterogyne spicata, and Uhl and Moore 1971, and Stauffer et al. 2002 for Geonoma interrupta). Thus, a symplicate zone is lacking. A central secretory protrusion is present between the three carpels, above the syncarpous zone, in Asterogyne and some species of Geonoma and Pholidostachys. Within Arecoideae the presence of such a central protrusion had previously only been reported in Butia (Uhl and Moore 1971).

Ovules are anatropous and crassinucellate, also in Welfia and Asterogyne, which were described as hemianatropous by Uhl and Dransfield (1987). Ovules are borne on a median placenta at mid-height of the ovary, but basal in Calyptrogyne ghiesbreghtiana and Geonoma. The papillate surface of the funiculus probably serves the transmission of pollen tubes towards the micropyle. Several studies on palm embryology (e.g. Venkata Rao 1959a, 1959b; Coccuci 1964; Shirke and Mahabale 1972) and general morphology of palm flowers (Uhl and Moore 1971, Uhl and Dransfield 1987) have indicated that the ovules are bitegmic. However, the study by Robertson (1976) on Jubaeopsis caffra is probably the only one including anatomical micrographs that unequivocally show the presence of two integuments.

In mature or near mature ovules of Geonomeae we could not clearly distinguish two integuments, not even the borderline between nucellus and (inner) integument was clear. Only in Geonoma maxima of which younger appropiate stages were available two integuments could be distinguished. In G. maxima, in contrast to Jubaeopsis, the basis of the inner integument is unusually thick (11-13 cell layers). The micropyle in ovules of Geonomeae, as in most Arecaceae, is in the median plane of the ovary, but in Calyptrogyne ghiesbreghtiana, it is directed to the side.

All species studied have a septal nectary formed by incomplete union of the carpel flanks and with a secretory epithelium of elongate, uninucleate cells. Asterogyne martiana has the most conspicuous epithelium, which is not only present on the carpel flanks but also on the central protrusion between the three carpels. The openings of the septal nectary are inconspicuous non-secretory ducts without an epithelium. From the literature one has the impression that the openings are at the same level in all three carpels in palms (see discussion in Uhl and Moore 1971). However, according to our observations this is not the case in Geonomeae. The openings of the nectaries are either towards the top of the ovary (Asterogyne, Calyptronoma Pholidostachys, Welfia), or at mid-height (Geonoma), or the two abaxial openings at the base and the adaxial one at mid-height of the ovary $(\mathrm{Ca}$ lyptrogyne). This is different from earlier reports of a position near the base of the ovary in Asterogyne martiana (Uhl and Moore 1977), and Geonoma (Uhl and Moore 1971), but supports results by Schmid (1983) in 
Asterogyne and Geonoma. The poorly differentiated septal nectary in Asterogyne spicata, as compared to other species of the genus, may be at least partially replaced in function by the papillate epidermis and internal slits of the free parts of the staminodes; however, the production of nectar from these slits should be tested in living material. The filaments of the male flowers of this species have also a papillate epidermis, but internal slits are only present in the filaments of abnormal stamens, frequently inserted at the periphery of the androecium (Stauffer et al. in press). Wessels Boer (1968) did not find nectaries in Geonomeae and pointed out that the exserted stamens and rather long, recurved, papillate stigmatic branches perhaps may be interpreted as an indication for wind pollination; however, this is contradicted by our finding of septal nectaries in all species studied. Moreover, several studies on the reproductive biology indicate insect or bat pollination in the tribe (e.g. Schmid 1970b; Henderson 1986; Olesen and Balslev 1990; Listabarth 1993, 1999; Borchsenius 1997; Knudsen 1999; Knudsen et al. 1999).

Carpels in Geonomeae normally have a dorsal vascular bundle, several lateral bundles and a ventral bundle complex, as described for Geonoma interrupta (Uhl and Moore 1971, Stauffer et al. 2002). Styles and stigmas are only served by one dorsal bundle, but in Asterogyne spicata and Welfia regia, there are additionally one or two bundles on each side of the ventral slit of the styles and stigmas, probably because of the large size of the gynoecium and fruit in these taxa. According to Uhl and Moore (1971) lack of histological protective devices in the long styles of Geono$m a$ (the only genus they studied of Geonomeae, which all have long styles) is compensated by submergence of flowers in pits covered by thick fibrous bracts. However, our study shows that in Geonoma protective histological devices are also present in the styles, as in the other floral parts. In Geonomeae, tanniferous tissue is spread in the mesophyll of the gynoecium, especially to- wards the top of the stigmatic branches, and cells with oxalate raphides are present in the perianth, and particularly concentrated in the staminodial tube and at the base of the styles.

Comparison of Geonomeae with other tribes of Arecoideae. Flowers deeply sunken in pits, floral parts united, at least at the base, in all whorls, and elongate and slender styles have been traditionally considered as the main shared characters within Geonomeae (Uhl and Dransfield 1987). Of these three characters, only the elongate styles may be considered as unique for Geonomeae among Arecoideae. Flowers deeply sunken in pits have also been described in Linospadicinae (Areceae) (Uhl and Dransfield 1987, Dransfield and Uhl 1998), and union of organs within all floral whorls is also present in Caryoteae p.p. and Cocoeae p.p. within Arecoideae.

Partial or total congenital union of sepals is present in all tribes of Arecoideae, except for Podococceae (with only one genus), but only characteristic for Bactridinae (Cocoeae) and Geonomeae. Congenital union of petals is restricted to Caryoteae, Areceae (only in Reinhardtia), Cocoeae (only in Gastrococos) and Geonomeae. The staminodes in the female flowers of Arecoideae show various degrees of differentiation and union (see Uhl and Dransfield 1987, for general review). Staminodes congenitally united at least at the base are present in all Cocoeae and Geonomeae, but only in a few Areceae and Caryoteae. Small and scale-like staminodes are present in several taxa of Areceae, e.g. species of Areca, Cyrtostachys and Ptychosperma (Al-Rawi 1945, Moncur 1988), and Dypsis (Rudall et al. in press). More differentiated staminodes, resembling normal stamens, except for size, were observed in Areca sp. (Venkata Rao 1959b) and Acrocomia (Uhl and Dransfield 1987). In Geonomeae, the staminodes are always united at least at the base and are differentiated in various ways. In Pholidostachys, Welfia, Asterogyne and Geonoma p.p., pollinators may be attracted by the stamen-like appearance of the staminodes, as suggested by Olesen and Balslev (1990) for Geonoma macrostachys. In taxa 
with a calyptrate androecium top (Calyptronoma, Calyptrogyne), attraction of pollinators may be by the light color of the bulging calyptra, contrasting with the otherwise dark rachillae (in a scarcely illuminated understory where the palms grow). Attraction of pollinators in Geonoma species with a less conspicuous upper part of the staminodes may be mainly by scent (Knudsen 1999, Knudsen et al. 1999) and heavy stigmatic secretion. The significance of the androecium diversity in the reproductive biology of Geonomeae is unknown and requires further investigation.

Among Arecoideae, gynoecia with all three carpels more or less equally developed are present in all tribes. They were studied in some detail in some Cocoeae (Al-Rawi 1945, Coccuci 1964, Uhl and Moore 1971) and Iriarteeae (Uhl and Moore 1971). Pseudomonomery based on three carpels occurs in Areceae, Iriarteeae and Geonomeae (all in Arecoideae) (Uhl and Dransfield 1987). In Areceae, among 17 subtribes, all are pseudomonomerous except for four triovulate genera in four subtribes (Dransfield and Uhl 1998). Geonoma is unique among Geonomeae in being pseudomonomerous (Eckardt 1937, Uhl and Moore 1971, Stauffer et al. 2002); the early retardation of two ovaries in Geonoma has traditionally been considered to be a derived character within the tribe (Uhl and Dransfield 1987). However, this was never tested in a phylogenetic context within Geonomeae or in Arecaceae in general. Uhl and Moore (1971) suggested that pseudomonomery had a separate origin in several groups of palms, e.g. in the "arecoid" and "iriarteoid" alliances (sensu Moore 1973). The pseudomonomerous gynoecium of Geonoma is externally more similar to that in Wettinia (Iriarteeae) than those in Areceae. As in Geonoma, in Wettinia quinaria (Uhl and Moore 1971) the styles appear to be basally attached and the gynoecium has a large fertile ovary and two small ovaries with reduced locules. In contrast, in the pseudomonomerous gynoecium of Ptychosperma (Areceae) (Uhl 1976b) and Dypsis (Areceae) (Rudall et al. in press), the stigmatic branches are on top of the ovary, and the sterile ovaries have the same size and shape as the fertile ovary. In pseudomonomerous gynoecia of Areceae the fertile and the sterile ovaries are almost equal in size and shape. Whereas in Geonomeae always one of the adaxial carpels is fertile, in Dypsis (Areceae) the abaxial one is fertile (Rudall et al. in press).

The stigmatic branches seem to be structurally uniform throughout Arecoideae. Even in pseudomonomerous taxa all three carpels have a well developed stigmatic branch. A stigmatic surface with unicellular papillae may be the most common condition in the subfamily, but apart from Geonomeae (this study) they were only studied in Butia (Cocoeae) (Coccuci 1964, Uhl and Moore 1971). Multicellular papillae and an especially large receptive area, as in Welfia, had been previosly mentioned only in Calyptrocalyx hollrungii (as Paralinospadix hollrungii), Areca langloisiana and Elaeis guineensis (Areceae) (Uhl and Moore 1971).

The elongate styles in Geonomeae are an exception within Arecoideae, in which styles are commonly almost lacking. In Wettinia and Geonoma the styles appear to be basal because of the lack of further development of the two sterile ovaries. In the rest of the subfamily, in taxa with pseudomonomerous, tri- or polymerous gynoecia the styles are either lateral or apical. Confluence of the secretory ventral slits of the stigmatic branches and formation of a compitum along the styles, which ends at the level of attachment of the ovules, have been occasionally reported in palms other than Geonomeae (e.g. Venkata Rao 1959b, Coccuci 1964, Uhl and Moore 1971, Rudall et al. in press).

Floral structure and systematics in Geonomeae. Some of the phylogenetic results by Roncal et al. (2002), based on molecular data, are supported by our study. Monophyly of Geonomeae is supported by the presence of an elongate style in all taxa studied. Monophyly of Geonoma is supported by the presence of a pseudomonomerous gynoecium, basal attachment of the ovule (in addition only observed in Calyptrogyne ghiesbreghtiana), and septal nectaries with openings at mid-height of the ovary. A close relationship between Calyptro- 
noma and Calyptrogyne was already pointed out by Wessels Boer (1968), but his taxonomic arrangement placing Calyptronoma as a subgenus of Calyptrogyne requires further investigation. Asmussen (1999b) found a sister relationship between Calyptronoma and $\mathrm{Ca}$ lyptrogyne, based on plastid rps16 DNA sequences, but Roncal et al. (2002) pointed out that Calyptronoma is paraphyletic with respect to Calyptrogyne, based on the nuclear gene phosphoribulokinase (PRK) and on intron 23 of RNA polymerase II subunit 2 (RPB2). It seems to be clear that there is a close relationship between these two taxa, which is further supported by the presence of a calyptrate synandrium (Uhl and Moore 1987, this study). Neither monophyly of Pholidostachys nor the sister relationship between Asterogyne and Geonoma are supported by our structural analysis. The isolated position of Welfia is supported by the presence of multicellular stigmatic papillae, which seems to be a rare feature. Nevertheless, the extensive fusion between the staminodial tube and the corolla, presence of numerous (more than six) staminodes, ovules attached at mid-height of the ovaries, and additional vascular bundles in the styles at anthesis, suggest affinity of Welfia with Asterogyne (see also Moore 1966); but this should be tested with additional morphological and molecular data.

The authors thank Rolf Rutishauser, Maria von Balthazar, Alex Kocyan, Rosemarie Siegrist, Mary Endress, and Merran Matthews for assistance with laboratory work or suggestions on the manuscript, and Urs Jauch for guidance with the SEM. Conny Asmussen, William Baker, Henrik Balslev, Finn Borchsenius, John Dransfield, Jette Knudsen, Christian Listabarth, Scott Zona and Natalie Uhl kindly provided important material for the comparative study. Julissa Roncal is greatly thanked for sharing unpublished data on the molecular phylogeny of Geonomeae. Special thanks go to the curators of the herbaria AAU, BH, $\mathrm{K}$ and US. Visits of Fred Stauffer to AAU and K were kindly granted by the Royal Botanic Gardens Kew Latin America Research Fellowships Program, and to US by the Program for Short Term Visits of the Smithsonian Institute (NMNH). The Ministerio del Ambiente y de los Recursos Naturales Renovables (MARNR) and the Instituto Nacional de Parques (Inparques) kindly provided the botanical permits for the collections in Venezuela.

Appendix 1. Additional material of Geonoma studied (species, collection, origin, stage of development)

Geonoma atrovirens Borchs. \& Balslev, H. Balslev (6430-AAU), Ecuador, old buds.

G. baculifera (Poit.) Kunth, F. W. Stauffer (18-Z), Venezuela, young buds.

G. brevispatha Barb. Rodr., D. Philcox (4606-K), Brazil, anthetic flowers.

G. congesta H. Wendl. ex Spruce, J. Knudsen (00:51-AAU), Costa Rica, anthetic flowers.

G. deversa (Poit.) Kunth, R. Bernal (2605-AAU), Colombia, anthetic flowers.

G. irena Borchs., H. Balslev (62018-AAU), Ecuador, young buds.

G. jussieuana Mart., T. Plowman (4977-K), Peru, old buds.

G. leptospadix Trail, B. Bergmann \& S. Laegaard (67236-AAU), Ecuador, old buds.

G. linearis Burret, A. Barfod \& F. Skov (60115-AAU), Ecuador, old buds.

G. longepedunculata Burret, H. Balslev et al. (62046-AAU), Ecuador, young buds.

G. orbignyana Mart., H. Balslev et al. (6457-AAU), Ecuador, old buds.

G. paradoxa Burret, F. Skov et al. (64716-AAU), Ecuador, old buds.

G. poeppigiana Mart., R. Bernal (2558-AAU), Colombia, anthetic flowers.

G. pohliana Mart., R. Harley (17853-K), Brazil, young buds.

G. polyandra Skov, J. Knudsen (96:18-AAU), Ecuador, young buds.

G. spinescens H. Wendl., F. W. Stauffer (19-Z), Venezuela, old buds.

G. stricta (Poit.) Kunth, J. Knudsen \& B. Stahl (96:55-AAU), Ecuador, anthetic flowers.

G. supracostata Svenning, B. Stahl (s.n.-AAU), Ecuador, anthetic flowers.

G. triglochin Burret, J. Knudsen (98:82-AAU), Ecuador, anthetic flowers.

G. undata Klotzsch, H. Balslev et al. (62489-AAU), Ecuador, old buds. 


\section{References}

Al-Rawi A. (1945) Blütenmorphologische und zytologische Untersuchungen an Palmen der Unterfamilie Ceroxyloideae. Ph.D. dissertation, University of Zurich. Orell Füssli, Zurich.

APG (1998) An ordinal classification for the families of flowering plants. Ann. Missouri Bot. Gard. 85: 531-553.

APG II (2003) An update of the Angiosperm Phylogeny Group classification for the orders and families of flowering plants: APG II. Bot. J. Linn. Soc. 141: 399-436.

Asmussen C. (1999a) Relationships of the tribe Geonomeae (Arecaceae) based on plastid rps16 DNA sequences. Acta Bot. Venez. 22: 65-76.

Asmussen C. (1999b) Toward a chloroplast DNA phylogeny of the Geonomeae (Palmae). In: Henderson A., Borchsenius F. (eds.) Evolution, variation and classification of palms. Mem. New York Bot. Gard. 83: 121-129.

Asmussen C., Chase M. (2001) Coding and noncoding DNA in palm systematics. Amer. J. Bot. 88: 1103-1117.

Barabé D., Chrétien L., Forget S. (1987) On the pseudomonomerous gynoecia of the Araceae. Phytomorphology 37: 139-143.

Borchsenius F. (1997) Flowering biology of Geonoma irena and G. cuneata var. sodiroi (Arecaceae). Plant Syst. Evol. 208: 187-196.

Burret M. (1930) Geonomeae Americanae. Bot. Jahrb. Syst. 63: 123-270.

Cocucci A. E. (1964) Sobre la embriología de Butia paraguayensis (Barb. Rodr.) Bailey (Palmae) con especial referencia a la taxonomía de la subfamilia Cocoideae. Trab. Mus. Bot. Córdoba 25: 15-19.

Dransfield J., Uhl N. (1998) Palmae. In: Kubitzki K. (ed.) Families and genera of vascular plants, flowering plants: monocotyledons, vol. 4, Springer, Berlin, pp. 306-389.

Drude O. (1881) Palmae. In: Martius K. F. P. v. Flora Brasiliensis 3: 253-283.

Drude O. (1889) Palmae. In: Engler A., Prantl K. (eds.) Die natürlichen Pflanzenfamilien 11, 3. Engelmann, Leipzig, pp. 1-93.

Endress P. K., Jenny M., Fallen M. (1983). Convergent elaborations of apocarpous gynoecia in higher advanced dicotyledons (Sapindales, Malvales, Gentianales). Nord. J. Bot. 3: 293300 .
Eckardt T. (1937) Untersuchungen über Morphologie, Entwicklungsgeschichte und systematische Bedeutung des pseudomonomeren Gynoeceums. Nova Acta Leop. 5: 1-112.

Gassner G. (1941) Über den Bau der männlichen Blüten und die Pollenentwicklung einiger Palmen der Unterfamilie der Ceroxylinae. $\mathrm{Ph} . \mathrm{D}$. dissertation, University of Zurich.

Hahn W. (2002) A molecular phylogenetic study of the Palmae (Arecaceae) based on $a t p \mathrm{~B}, r b c \mathrm{~L}$ and $18 \mathrm{~S}$ nrDNA sequences. Syst. Biol. 51: 92-112.

Hartl D., Severin I. (1981) Verwachsungen im Umfeld des Griffels bei Allium, Cyanastrum und Heliconia und den Monokotylen allgemein. Beitr. Biol. Pfl. 55: 235-260.

Henderson A. (1986) A review of pollination studies in the Palmae. Bot. Rev. 52: 221-259.

Henderson A., Galeano G., Bernal R. (1995) Field guide to the palms of the Americas. Princeton University Press, Princeton, New Jersey.

Heslop-Harrison Y., Shivanna K. R. (1977) The receptive surface of the angiosperm stigma. Ann. Bot. 41: 1233-1258.

Igersheim A., Cichocki O. (1996) A simple method for microtome sectioning of prehistoric charcoal specimens, embedded in 2-hydroxyethyl methacrylate (HEMA). Review Palaeobot. Palynol. 92: 389-393.

Igersheim A., Buzgo M., Endress P. K. (2001). Gynoecium diversity and systematics in basal monocots. Bot. J. Linn. Soc. 136: 1-65.

Knudsen J. (1999) Floral scent differentiation among coflowering, sympatric species of Geonoma (Arecaceae). Pl. Spec. Biol. 14: 137-142.

Knudsen J., Andersson S., Bergman P. (1999) Floral scent attraction in Geonoma macrostachys, an understorey palm of the Amazonian rain forest. Oikos 85: 409-418.

Listabarth C. (1993) Pollination in Geonoma macrostachys and three congeners, G. acaulis, G. gracilis and G. interrupta. Bot. Acta 106: 496-506.

Listabarth C. (1999) Pollination studies of palm populations: a step toward the application of a biological species concept. In: Henderson A., Borchsenius F. (eds.) Evolution, variation, and classification of palms. Mem. New York Bot. Gard. 83: 81-93.

Moncur M. (1988) Floral development of tropical and subtropical fruit and nut species. Natural 
Resources Series No. 8. Division of Water and Land Resources, Melbourne.

Moore H. E. (1966) Aristeyera, a new genus of geonomoid palms. J. Arnold Arbor. 47: 1-8.

Moore H. E. (1973) The major groups of palms and their distribution. Gentes Herb. 11: 27-141.

Müller-Doblies U. (1970) Über die Verwandtschaft von Typha und Sparganium in Inflorescenz und Blütenbau. Bot. Jahrb. Syst. 89: 451-562.

Olesen J., Balslev H. (1990) Flower biology and pollinators of the Amazonian monoecious palm, Geonoma macrostachys: a case of Bakerian mimicry. Principes 34: 181-190.

Robertson B. (1976) Embryology of Jubaeopsis caffra Becc.: 2. Megasporangium, megasporogenesis and megagametogenesis. J. S. Afr. Bot. 42: $173-184$.

Roncal J., Lewis C., Asmussen C., FranciscoOrtega J. (2002). Molecular phylogenetics of the palm tribe Geonomeae (Arecaceae). Botany 2002 - Meeting of the Botanical Society of America, Madison. Abstract 581.

Ronse Decraene L. P., Smets E. F. (1998) Meristic changes in gynoecium morphology, exemplified by floral ontogeny and anatomy. In: Owens S. J., Rudall P. J. (eds.) Reproductive biology. Royal Botanic Gardens, Kew, pp. 85-112.

Ronse Decraene L. P., Linder H. P., Smets E. F. (2001) Floral ontogenetic evidence in support of the Willdenowia clade of South African Restionaceae. J. Plant Res. 114: 329-342.

Ronse Decraene L. P., Linder H. P., Smets E. F. (2002) Ontogeny and evolution of the flowers of South African Restionaceae with special emphasis on the gynoecium. Plant Syst. Evol. 231: 225258.

Rudall P., Abranson K., Dransfield J., Baker W. (2003) Floral anatomy in Dypsis (ArecaceaeAreceae): a case of complex synorganization and stamen reduction. Bot. J. Linn. Soc. (in press).

Schmid R. (1970a) Notes on the reproductive biology of Asterogyne martiana (Palmae). I. Inflorescence and floral morphology, phenology. Principes 14: 3-9.

Schmid R. (1970b) Notes on the reproductive biology of Asterogyne martiana (Palmae). II. Pollination by syrphid flies. Principes 14: 39-49.

Schmid R. (1983) Septal nectaries of Asterogyne martiana and other Palmae. Principes 27: 168174.
Shirke N., Mahabale T. (1972) Studies on palms: embryology of Caryota urens L. In: Murty Y. B., Johri H., Mohan Ram H., Varghese T. (eds.) Advances in plant morphology. Prabhat Press, Meerut, pp. 218-232.

Spruce R. (1871) Palmae Amazonicae. J. Linn. Soc. Bot. 11: 65-183.

Stauffer F. W., Rutishauser R., Endress P. K. (2002) Morphology and development of the female flowers in Geonoma interrupta (Arecaceae). Amer. J. Bot. 89: 220-229.

Stauffer F. W., Asmussen C. B., Henderson A., Endress P. K. (2003). A revision of Asterogyne (Arecaceae: Arecoideae: Geonomeae). Brittonia (in press).

Uhl N. (1966) Morphology and anatomy of the inflorescence axis and flowers of a new palm, Aristeyera spicata. J. Arnold Arbor. 47: 922.

Uhl N. (1988) Floral organogenesis in palms. In: Leins P., Tucker S. C., Endress P. K. (eds.) Aspects of floral development. Cramer, Berlin, pp. 25-44.

Uhl N., Dransfield J. (1984) Development of the inflorescence, androecium and gynoecium with reference to palms. In: White R. A., Dickison W. C. (eds.) Contemporary problems in plant anatomy. Academic Press, New York, pp. 397449.

Uhl N., Dransfield J. (1987) Genera Palmarum: a classification of palms based on the work of H. E. Moore Jr., L. H. Bailey Hortorium, and the International Palm Society. Allen Press, Lawrence, Kansas.

Uhl N., Moore H. E. (1971) The palm gynoecium. Amer. J. Bot. 58: 945-992.

Uhl N., Moore H. E. (1977) Correlations of inflorescence, flower structure and floral anatomy with pollination in some palms. Biotropica 9: 170-190.

Uhl N., Moore H. E. (1980) Androecial development in six polyandrous genera representing five major groups of palms. Ann. Bot. 45: $57-75$.

Uhl N., Dransfield J., Davis J. I., Luckow M. A., Hansen K. S., Doyle J. J. (1995) Phylogenetic relationships among palms: Cladistic analyses of morphological and chloroplast DNA restriction site variation. In: Rudall P., Cribb P. J., Cutler D. F., Humphries C. J. (eds.) Monocotyledons, 
F. W. Stauffer and P. K. Endress: Comparative morphology and systematics in Geonomeae

systematics and evolution. Royal Botanic Gardens, Kew, pp. 623-661.

Venkata Rao C. (1959a) Contributions to the embryology of Palmae. I. Sabaleae. Proc. Nat. Inst. Sci. India 25:143-169.

Venkata Rao C. (1959b) Contributions to the embryology of Palmae. II. Ceroxylinae. J. Indian Bot. Soc. 38: 46-75.

Wessels Boer J. G. (1968) The geonomoid palms. Verh. Kon. Ned. Akad. Wetensch., Afd. Natuurk., Tweede Sect. 58: 1-202.
Zona S. (1995) A revision of Calyptronoma (Arecaceae). Principes 39: 140-151.

Address of the authors: Fred W. Stauffer (e-mail: f.stauffer@access.unizh.ch), Peter K. Endress, Institute of Systematic Botany, University of Zurich, Zollikerstrasse 107, CH-8008 Zurich, Switzerland. 